Andrews University

Digital Commons @ Andrews University

1987

\title{
An Experiment in Ministering to Felt Needs of a Small Church Through Contemporary Sabbath Services
}

Dwayne Toppenberg

Andrews University

Follow this and additional works at: https://digitalcommons.andrews.edu/dmin

Part of the Practical Theology Commons

\section{Recommended Citation}

Toppenberg, Dwayne, "An Experiment in Ministering to Felt Needs of a Small Church Through Contemporary Sabbath Services" (1987). Professional Dissertations DMin. 705.

https://dx.doi.org/10.32597/dmin/705

https://digitalcommons.andrews.edu/dmin/705

This Project Report is brought to you for free and open access by the Graduate Research at Digital Commons @ Andrews University. It has been accepted for inclusion in Professional Dissertations DMin by an authorized administrator of Digital Commons @ Andrews University. For more information, please contact repository@andrews.edu. 
ABSTRACT

AN EXPERIMENT IN MINISTERING TO FELT NEEDS OF A SMALL CHURCH THROUGH CONTEMPORARY SABBATH SERVICES

by

Dwayne $R$. Toppenberg

Chairman: Reuben A. Hubbard 


\title{
ABSTRACT OF GRADUATE STUDENT RESEARCH \\ Project Report
}

\author{
Andrews University
}

Seventh-day Adventist Theological Seminary

Title: AN EXPERIMENT IN MINISTERING TO FELT NEEDS OF A SMALL CHURCH THROUGH CONTEMPORARY SABBATH SERVICES

Name of Researcher: Dwayne R. Toppenberg

Name and degree of chairman: Ruban A. Hubbard, D.Min.

Date completed: May 1986

Problem

Jesus came to give fullness of life and yet people leave the church because of unsatisfying interpersonal relationships. It was the task of this project to measure the effects of Sabbath services upon the interpersonal relationships between church members.

\section{Method}

Ten Sabbath services were specifically designed to improve the interpersonal behaviors of inclusion, 
control, and openness, and to stimulate the interpersonal feelings of significance, competence, and love. The Schutz Measures instrument was administered before and after the ten services to determine whether these behaviors and feelings had improved.

\section{Results}

The scores on the schutz instrument revealed that improvements were realized for the feelings of significance, competence, and love, and the behaviors of inclusion and control. Even though the congregation's score on openness moved slightly toward desiring more privacy, the intensity of the desire for openness also improved.

\section{Conclusions}

The average number of members and visitors attending weekly during the study was only nineteen, so conclusions can not be generalized; however, the evidence indicated that the use of ten-minute prayer-request times, life-situational sermons, post-sermon discussions, and instruction on felt needs helped the congregation to feel that interpersonal relationships had improved. 


\title{
Andrews University \\ Seventh-day Adventist Theological Seminary
}

\section{AN EXPERIMENT IN MINISTERING TO FELT NEEDS OF A SMALL CHURCH THROUGH CONTEMPORARY SABBATH SERVICES}

\author{
A Project Report \\ Presented in Partial Fulfillment \\ of the Requirements for the Degree \\ Doctor of Ministry
}

by

Dwayne Toppenberg

May 1987 


\section{AN EXPERIMENT IN MINISTERING TO FELT NEEDS OF A SMALL CHURCH THROUGH CONTEMPORARY SABBATH SERVICES}

A project report presented in partial fulfillment of the requirements for the degree Doctor of Ministry

by

Dwayne $R$. Toppenberg

APPROVAL BY THE COMMITTE:

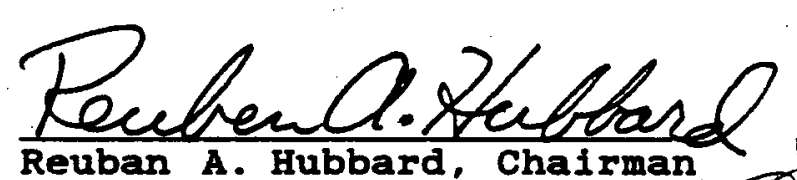

Reuban A. Hubbard, Chairman

Conen

C. Raymond Holmes

$\frac{\text { O. Werry haxwell }}{\text { c. Merprn paxwe11 }}$

$\frac{29 \text { Mor } / 9 B>}{\text { Date approved }}$


LIST OF TABLES . . . . . . . . . . . . . . . . . . vi vi

INTRODUCTION . . . . . . . . . . . . . . . . . 1

Justification for the Project . . . . . . . . 1

Having a Full Christian Life Necessitates

Improving Interpersonal Relationships . 1

An Assumption: Worship Should Be

Therapeutic to Interpersonal

Relationships . . . . . . . . . . . . . 2

Study of the Effects of Worship Is Needed. 2

Purpose of the Project . . . . . . . . . . . . 4

Definition of Terms . . . . . . . . . . . . . 5

Inclusion ................ . 5

Control . . . . . . . . . . . . . . . . . 5

Openness . . . . . . . . . . . . . . . . . 6

Significance . . . . . . . . . . . . . . . 6

Competence . . . . . . . . . . . . . . . . 7

Likability . . . . . . . . . . . . . . . . 7

Contemporary Music . . . . . . . . . . . . 7

Felt Needs . . . . . . . . . . . . 8

Church Life . . . . . . . . . . . . . . . 9

Project Preparations . . . . . . . . . . . . . 9

The Choice of a Small Church . . . . . . . . 10

Limitations of the Project . . . . . . . . . . 10

Chapter

I. PERTINENT CITY AND CHURCH DEMOGRAPHICS . . . 11

Demographic Profile of the City . . . . . 11

Demographic Profile of the Church . . . . . 11

Church Attendance......... . . 11

Age of Church Members . . . . . . . . . 12

The Number of Male and Female Members . 14

Education Levels of Members . . . . . 15

II. THE NEW SABBATH SERVICES . . . . . . . . . . 17

The Worship Service . . . . . . . . . . . 18

9:15 - 9:45 Contemporary Music

and Church Life........... . 18

Music (First Segment)....... . 18

Interview (Church Life)....... 18 
Music (Second Segment) . . . . . 19

Announcements (First Part). . . . 19

Music (Third Segment) . . . . . . . 19

Announcements (Second Part) . . . 20

Music (Fourth Segment) . . . . . 20

$9: 45$ - 9:55 Prayer Request and

Needs Prayer . . . . . . . . . 20

$9: 55$ - 10:20 Life-Situational sermon . 22

10:20 - 10:35 Discussion of

Applications . . . . . . . . . 23

$10: 35$ - 10:45 Dedication, offering

and Benediction... . . . . . 23

Sabbath School . . . . . . . . . . . . 24

10:55 - 11:05 Contemporary Music

Song Service . . . . . . . . . . . 24

11:05 - 11:25 Instruction on Needs or

Mission Report . . . . . . . . . 24

11:25 - 12:00 Sabbath School Lesson

study .............. . 25

A Note about Project Preparations . . . . 26

Choice of Contemporary Music . . . . . . 26

Reason for Selecting Contemporary

Music............... . 26

Method of Selecting the Contemporary

Music............... . 27

Introduction of the Contemporary

Music . . . . . . . . . . . . 28

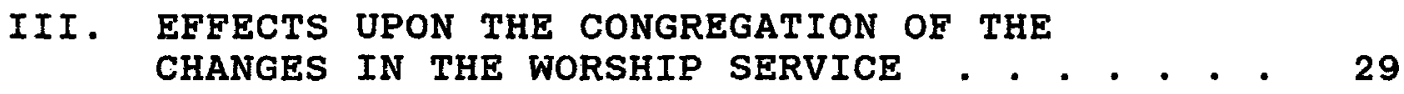

First Sabbath Evaluation . . . . . . . 29

Fifth Sabbath Evaluation . . . . . . . 32

Seventh Sabbath Evaluation . . . . . . . . 37

Contemporary Music . . . . . . . . . 38

Church Life. . . . . . . . . . . . . . 38

Prayer Request Time . . . . . . . . . 38

Life-Situational Sermons . . . . . . . 39

Formality of Opening and closing

Worship . . . . . . . . . . . . 39

Post-Sermon Discussion . . . . . . . 39

Sabbath School Discussion. . . . . . 40

Last Sabbath Evaluation... . . . . . 40

IV. THE SChUTZ MEASURE . . . . . . . . . . . . . 49

Description of the Schutz Measure... . . 49

Reliability of the Instrument... . . . . 51

Effects of the Ten Worship Services upon

the Six Elements of the Instrument

and the Conclusions of Each Element. . 51

Inclusion. . . . . . . . . . . . . 51 


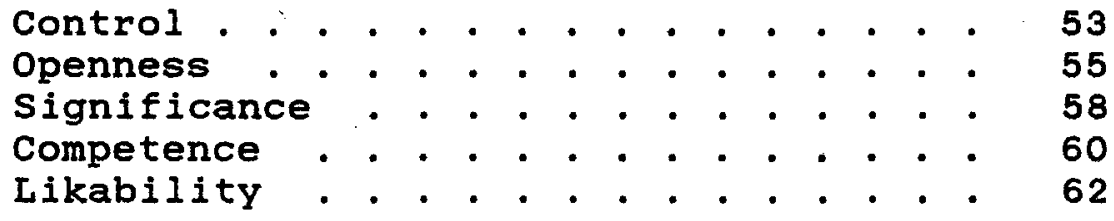

V. EVALUATION OF THE PROJECT IN THE LIGHT OF THE THEOLOGY AND HISTORY OF THE PRACTICE

OF WORSHIP . . . . . . . . . . . . . . . .

Historical Knowledge Needed . . . . . .

Five Essential Elements of Worship and an

Evaluation of the Use of Each During

the Project... . . . . . . . . . . 65

Remembering and Reliving . . . . . . 65

God's Self-Giving . . . . . . . . . . 68

Adoration . . . . . . . . . . . . 70

Reverence . . . . . . . . . . . . . 71

Fellowship . . . . . . . . . . . . 75

Dedication to Service . . . . . . . 78

VI. SUMMARY OF THE PROJECT, RECOMMENDATIONS, AND

PERSONAL VALUE OF THE PROJECT . . . . . . . . 82

Summary of the Project . . . . . . . 82

Needs--The Starting Point. . . . . . 82

Worship Was Therapeutic . . . . . . . 82

Other Benefits Realized... . . . . 83

Another Look at Attendance . . . . . . 84

Crises Stimulate Attendance. . . . 84

Ministry to Needs Stimulate Church

Attendance . . . . . . . . . 85

Conclusion Concerning Lower Church

Attendance . . . . . . . . . . 86

Recommendations Arising from the Project. . 87

Instruction for Beginners Versus

Advanced Instruction for Members . 87

Participation Versus Observation . . . 91

Add a Second Service . . . . . . . . . 94

Listen, Acknowledge, and Touch . . . . 95

Positiveness and Affirmation . . . . . 99

Watch and Respond . . . . . . . . . . . 100

Assistance Versus Leadership . . . . 100

Stress and Sharing Experiences . . . . 101

Altar Calls. . . . . . . . . . . . 101

Annual Evaluations . . . . . . . . 102

More Verification Needed . . . . . . 102

Personal Value of the Project. . . . . . . 103

APPENDICES . . . . . . . . . . . . . 105

BIBLIOGRAPHY . . . . . . . . . . . . . . 120 


\section{LIST OF TABLES}

1. Age Groups of the Church Membership . . . . . 13

2. Gender of the Church Membership . . . . . . . . 14

3. Educational Level of the Church Members . . . . 16

4. Measurement of Inclusion . . . . . . . . . . 52

5. Measurement of Control . . . . . . . . . . 54

6. Measurement of Openness . . . . . . . . . 56

7. Measurement of Significance . . . . . . . . 59

8. Measurement of Competence . . . . . . . . . 61

9. Measurement of Likability . . . . . . . . . . 63 


\section{ACKNOWLEDGMENTS}

Grateful appreciation is expressed to C. Raymond Holmes, Director of the Doctor of Ministry program, for his challenges and suggestions; to Dr. Ruban T. Hubbard, committee chairman, who gave assurance, and provided direction; and to Dr. C. Mervyn Maxwell for his constructive criticism.

I am grateful to Joyce Jones and Gayle Saxby for their extensive reading and editorial assistance.

Behind every successful man is a successful woman and I wish to give my greatest appreciation to my wife, Janet, for her forty plus hours per week work to not only put me through the Seminary program but at the same time to put our two children through their years in academy. She certainly deserves her Ph.T. (Put Hubby Through) degree!

In the background of all my work is the memory of my father, David R. Toppenberg, M.D., who, resting at the Malamulo Mission in Malawi, Africa, waiting the Lord's return, left me a picture of consistent daily 5 a.m. devotions with God. Many times his inspiration has carried me on.

May God be glorified. 


\section{INTRODUCTION}

\section{Justification for the Project}

i1

Having A Full Christian Life Necessitates Improving Interpersonal Relationships

For eighteen years as a Seventh-day Adventist minister I have been listening to those who no longer attend church regularly. From them I hear that the church neither understands their reasons for not attending church nor ministers to certain voids in their lives. Jesus said, "I have come that they may have life, and have it to the full."1 It seems ironic that Jesus came to give a full life, yet people leave the church because of an unfilled need.

During six years of mission service I saw health and educational needs being met. Ministry to such needs is typically called "lift." Even though Americans are often more affluent, the presentation of the gospel should bring lift to them--should improve their interpersonal relationships, for example.

When John the Beloved prayed "that you may enjoy good health and that all may go well with you, even as

\section{${ }^{1} \mathrm{John}$ 10:10. All biblical quotations are from} the NIV 
your soul is getting along well," ${ }^{1}$ he wished for Christians to have an improved life. Paul encouraged improved interpersonal relationships when he exhorted, "Encourage one another and build each other up." 2 Alas, inactive members have stopped attending church because there are voids in their lives that have not been filled during Sabbath services.

An Assumption: Worship Should

Be Therapeutic to Inter-

Personal Relationships

Dr. Will Schutz, author of The Schutz Measures, believes that three behaviors--inclusion, control, and openness--give rise to feelings of significance, competence, and likability, and that these behaviors and feelings greatly affect interpersonal relationships. ${ }^{3}$ I am assuming that one's worship of God should improve one's behavior as well as one's feelings toward other people.

Study of the Effects of Worship Is Needed

When worship is both therapeutic and Biblical, it not only involves bowing in silent, humble reverence

$1_{3}$ John 2.

${ }^{2}$ Thess $5: 11$.

${ }^{3}$ Will Schutz, Professional Manual, The Schutz Measures, research ed. (Palo Alto, CA: Consulting Psychologists Press, 1983), p. 2 . 
before God, ${ }^{1}$ it may also include expressions of joy, such as shouting, rejoicing, clapping hands, and dancing. ${ }^{2}$ David, "wearing a linen ephod," worshiped joyfully when he "danced before the Lord." 3

Commenting on Jesus' words about fasting, Ellen White speaks of expressing joy in every activity:

Whatever is done to the glory of God is to be done with cheerfulness, not with sadness and gloom. There is nothing gloomy in the religion of Jesus. If Christians give the impression by a mournful attitude that they have been disappointed in their Lord, they misrepresent $H$ is character and put arguments into the mouth of His enemies. Though in words they may claim God as their Father, yet in gloom and sorrow they present to the world the aspect of orphans.

Even though worshipers need to express reverence and joy in worship, David Wilkinson and Paul obregon indicate that worshipers also need to hear sermons that are life-situational rather than merely expository, that concentrate on the needs of the unchurched. ${ }^{5}$ In addition, Rick Warren indicates that lively music, not in

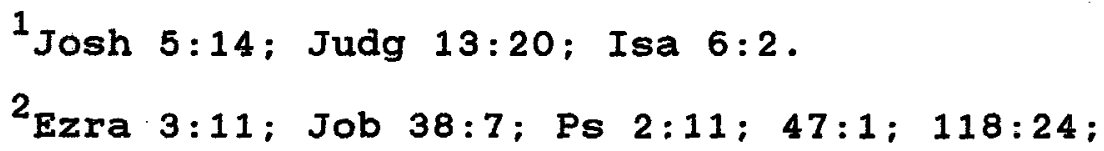

${ }^{4}$ Mount of Blessing, standard paging ed. (Mountain View, CA: Pacific Press Publishing Association, 1956), p. 88 .

5 "Urban Heart Beat," (N.p.: Southern Baptist Home Mission Board, 1982.) 
a minor key, is needed in worship. ${ }^{1}$

The fact that the membership of the Milwaukie, Oregon, SDA Church increased by 75 percent in three years, $^{2}$ while the pastor, Dave snyder, used lifesituational sermons and lively music, would indicate that a void in people's lives was filled during worship.

Thus it appears that some changes in worship have widened the spectrum of people churches can serve effectively. More study as to the effect of these changes is needed.

\section{Purpose of the Project}

The purpose of this project was to determine whether higher scores for the behaviors of inclusion, control, and openness, and the feelings of significance, competence, and likability, as measured by the schutz Measures, would be attained after selected changes in the Sabbath services were made and church ministry to felt needs was instituted in a small church in a Midwest city. It was not the purpose of this project to study the nature of worship exhaustively, nor was it the purpose to make a thorough study of ways to minister to the needs felt by this congregation.

\section{${ }^{1}$ Rick Warren, How To Plant A Church Workshop} (workbook), Fuller Theological Seminary, Atlanta, October 28-30, 1986 .

${ }^{2}$ Church growth January 1983 to December 1986 has been from 342 to 600 members. 


\section{Definition of Terms}

The Schutz Measures instrument ${ }^{1}$ is designed to measure the interpersonal behaviors of inclusion, control, and openness, and the basic feelings of significance, competence, and likability. Each is defined here.

Inclusion: People differ in the amount of interpersonal contact they want to have. Some are sanguine, the life of the party. Others are melancholic, prefer$r$ ing to be alone. Inclusion is the behavior that is

. . . concerned with achieving just the right amount of contact with people. . . how much we desire to be with other people and how much we wish to be alone; how much we want to be in groups with other people and how much we want to avoid groups.

Control: As people differ in the amount of contact they like to have with others, so people differ in their desires about control. This element is concerned with

. . achieving just the right amount of control over people. Some people are more comfortable when they are in charge of everyone. They like to be the boss, to give orders, to make decisions both for themselves and for others.

other people prefer to have no control over others. They are content never to tell people what to do. They even seek out situations where they have no responsibility.

instrument.

${ }^{1}$ See Chapter 4 for a description of the

$$
\begin{aligned}
& { }^{2} \text { schutz, p. } 6 . \\
& { }^{3} \text { Ibid., p. } 6 .
\end{aligned}
$$


Openness: The last behavior evaluated in the

Schutz instrument is openness: the amount that one reveals himself or keeps his life secret.

Some people enjoy relationships with others where they talk about their feelings, their secrets and their innermost thoughts. They enjoy having one, or at most a few, people in whom they confide. other people. . . . would rather keep things impersonal and prefer to have acquaintances rather than to have a few close friends.

These behaviors are not pointed out as being either desirable or undesirable, but rather as differing from person to person. The benefit of the schutz instrument is the awakening of awareness of preferences in relationships.

The feeling elements of the schutz instrument are significance, competence, and likability.

Significance: A person feels significant if he is listened to, remembered, touched, talked to, or acknowledged. In contrast, a person feels insignificant if he is ignored, forgotten, or rejected. ${ }^{2}$ one can be made to feel he is significant even though he may not be liked, or even if he is less competent than others.

$$
\begin{aligned}
& { }^{1} \text { Ibid., p. } 6 . \\
& { }^{2} \text { Ibid., p. } 9 .
\end{aligned}
$$


Competence: This measures one's ability to satisfy needs, to prevent trouble, to cope with life. It refers to the

to be self-sufficient, and to achieve something substantial.1. . to make decisions and to solve problems.

The author uses child-training as an illustration when he continues.

When children are severely restricted and have everything done for them, their parents are giving them the message that the chjldren are not competent to make their own decisions.

Likability: People may be significant and competent but not likeable, for this is based on the

- . ability to create an atmosphere within which people like themselves. I find you likeable if I like how I behave and feel in your presence. Paradoxically, my liking has very little to do with you. I like you if I like myself when I am with you. . . When parents reject children they are communicating that they do not find the children likeable. They convey this feeling by not being happy when they are with their children. Children often get the feुeling that 'There must be something wrong with me.'

Two other terms that need defining are contemporary music and felt needs.

Contemporary Religious Music: This term is difficult to define. At first I thought the contemporary

${ }^{1}$ Ibid., p. 9.
${ }^{2}$ Ibid., p. 9.
${ }^{3}$ Ibid., p. 9. 
music was faster than the music found in the church hymnal so I compared the tempo of the two classes of music. I discovered the average tempo of the contemporary music was only six beats per minute faster than the average tempo of thirty randomly selected songs from the hymnal. For the purpose of this project, I have defined contemporary religious music as that religious music written or arranged within the last two decades which is of a quality that might be sung by Bill Gaither or the Heritage singers. The tape used during the project was volume one and two of Magnify the Lord. ${ }^{1}$ This tape includes such songs as "Jesus Is Lord of All," "Jesus, We Just Want to Thank You," and, "Redeeming Love," by Bill Gaither, "He Giveth More Grace," by Flint-Mitchell, and "He Will Carry You," by Brown.

Felt Needs: Prior to the commencement of this project a survey was sent to 300 randomly selected residents to determine their felt needs. ${ }^{2}$ The areas people most frequently marked as urgent were: (1) childtraining, (2) family finances, and (3) marriage assistance. Stress management scored almost as frequently as an urgent need. This project was designed to help people feel they are understood, appreciated, and

${ }^{1}$ (Kansas City, MO: Pilot Point Music, 1986)

${ }^{2}$ See Appendix A for the survey. 
loved by ministering to these needs during the Sabbath services.

Church Iife: Dave Snyder, pastor of the Milwaukie, Oregon, SDA church, has integrated church announcements, personal ministries, and other church activities into one segment of the worship service and has called it "Milwaukie Church Life." Following his example, I interspersed congregational singing with church announcements, personal ministries, special music, and interviews of worship speakers, selected guests and members. I called this section "Church Life."

\section{Project Preparations}

In preparation for this project, I attended the project church from October 1985 through the commencement of the project in January 1987. I visited each member, whether active or inactive, and observed the program of the church. I taught the adult Sabbath School class most of that time. Beginning May 3,1986 the Schutz Measures instrument was administered--first to active members at the church, and then to inactive members in their homes. Four months prior to commencing the project, the church began a monthly ten-minute prayer request time in the worship services. During the project, this prayer request time was a part of the worship service each week. Two months before the commencement of the project, the church began using contemporary music for song services 
during Sabbath school. During the first seven weeks of the project, this type of music was used, in addition to music from the Church Hymnal, during all services.

\section{The Choice of a Small Church}

Because many small churches have unique problems due to their size, I chose to work with a church of forty-six members. One problem is that members of small congregations often think their churches can not and need not minister to felt needs. Another problem is that often the members do not realize that in the community there are organizations that minister to felt needs and that speakers from these organizations are available to the small church.

\section{Iimitations of the Project}

I anticipated that some of the principles learned here would be applicable to congregations of various sizes. It must be recognized, though, that using a small congregation for such a study means that some conclusions can not be generalized. 


\section{CHAPTER ONE}

\section{PERTINENT CITY AND CHURCH DEMOGRAPHICS}

The purpose of this chapter is to state selected demographics of the city and church of this study project and some of the effects these demographics may have had on the project.

\section{Demographic Profile of the City}

The project was conducted in a Midwest city which in 1980 counted a population of 36,850 which population was decreasing at a rate of 6.4 percent per decade; meanwhile the state population was increasing at a rate of 5.7 percent. of the twenty-four cities in the state, this city ranks eighteenth in size, twentieth in population density, and 20.85 percent of its population is black. It ranks fourth in the state for percentage of black population.

\section{Demographic Profile of the Church}

\section{Church Attendance}

$$
\text { Forty-six members are listed on the church }
$$

records; thirteen no longer live in the area. of the thirty-three who could attend, the average attendance for the thirty-eight weeks prior to the project was 20.26 
people per Sabbath. ${ }^{1}$ During the ten weeks of the project the average attendance was 18.70 people per Sabbath, which represents a drop of 7.7 percent. Although it is probable that the attendance for the first quarter of any year would be lower than for the other three quarters, in consequence of cold and inclement winter weather, whether this drop was due to the winter weather could be determined only if the attendance during the ten-week project were compared with the same ten-week period of prior years. However, such attendance data are not available.

The average number of adult visitors attending during the thirty-eight weeks was 3.39 per sabbath. 2 The average number of visitors attending during the project was 3.11 per Sabbath. Even as I assumed that the attendance for the project was 7.7 percent lower than average because of inclement winter weather, so I assume the number of visitors was 8.3 percent lower for the same reason. 3

Age of Church Members

Since the 1980 median age for the city was twenty-nine, and the median age for church members--

${ }^{1}$ For the second, third, and fourth quarter 1986, the averages were as follows: $19.62,21.31,19.83$.

2 For the second, third, and fourth quarters, 1986 , the averages were as follows: $2.69,5.31,2.08$.

${ }^{3}$ see chapter 6 , page 81 for a discussion of the reasons. 
including children--was thirty-eight, the members of the church were older than the general population. Table 1 shows the membership as divided into several age groups. 1

TABLE 1

AGE GROUPS OF THE CHURCH MEMBERSHIP

\begin{tabular}{lcccc}
\hline $\begin{array}{l}\text { Age } \\
\text { Group }\end{array}$ & $\begin{array}{l}\text { Active } \\
\text { Member }\end{array}$ & $\begin{array}{l}\text { Inactive } \\
\text { Member }\end{array}$ & Total & Ratio* \\
\hline $16-20$ & 2 & 2 & 4 & .80 \\
$21-30$ & 2 & 1 & 3 & .30 \\
$31-45$ & 7 & 5 & 12 & .80 \\
$46-65$ & 5 & 2 & 7 & .35 \\
$66-75$ & 2 & 1 & 3 & .30 \\
\hline
\end{tabular}

*Ratio is the number of members in the group divided by the number of years in the segment.

Research done by Will Schutz indicates that the desire for inclusion peaks between thirty to thirty-nine years of age, and that the desire for openness decreases with age ${ }^{2}$ but is still strong between the ages of thirty and thirty-nine. ${ }^{3}$ Therefore, since the 16-to-20 and

${ }^{1}$ Individuals under sixteen were not included in the following tables as they were not given the Schutz instrument.

2 The exception is for the age group over 50 .

${ }^{3}$ schutz, p. 7,8 . 
31-to-45 age groups had the largest "ratio," as defined in table 1, the church should have a high desire for both openness and inclusion, and since the percentage of members who are in these groups is slightly larger for inactive than active members, ${ }^{1}$ these desires should be stronger for the inactive members. ${ }^{2}$

The Number of Male and Female Members

Table 2 shows the number of male and female members in the project congregation. Eighty-two percent of the inactive and 67 percent of active members are female.

TABLE 2

GENDER OF THE CHURCH MEMBERSHIP

\begin{tabular}{lll}
\hline Sex & $\begin{array}{l}\text { Active } \\
\text { Members }\end{array}$ & $\begin{array}{l}\text { Inactive } \\
\text { Members }\end{array}$ \\
\hline
\end{tabular}

M

6

2

F

12

9

${ }^{1}$ sixty-four percent of inactive and 50 percent of active members are in these age groups.

${ }^{2}$ See pp. 51 and 55 respectively for the comparative results of the inclusion and openness elements of the schutz instrument. 
Concerning the possible effects of gender differences upon inclusion and control will schutz says:

Women tend to include each other while men maintain a more independent air. . . The picture of control. . follows the cultural stereotype. Males are higher on I want to Control People.

Because of the large percentage of women in the church, I would expect the Schutz values for inclusion and control to be $\mathrm{high}^{2}$.

\section{Education Levels}

of Members

The maximum levels of education achieved by the members are listed in table 3. Seventeen percent of the membership achieved only an elementary education. While 37 percent of the total membership have finished high school, the percentage of inactive memmbers who have done so is twice that of active members. ${ }^{3}$ Fourteen percent more inactive than active members have finished four years of college. 4 Because inactive members have achieved more education than active members it might be expected that they, rather than the active members, would be more open to change, more interested in the instruction and

${ }^{1}$ schutz, p. 8 .

${ }^{2}$ see pp. 51 and 53 respectively for the comparative results of the inclusion and control elements of the schutz instrument.

${ }^{3}$ Fifty-five percent of inactive and 28 percent of active members have finished high school.

${ }^{4}$ Thirty-six percent of inactive and 22 percent of active members, for a 27 percent total, have finished college. 
TABLE 3

EDUCATIONAL LEVEL OF THE CHURCH MEMBERS

\begin{tabular}{lcc}
\hline $\begin{array}{l}\text { Maximum Level } \\
\text { Completed }\end{array}$ & $\begin{array}{l}\text { Active } \\
\text { Members }\end{array}$ & $\begin{array}{l}\text { Inactive } \\
\text { Members }\end{array}$ \\
\hline Elementary & 4 & 1 \\
High School & 5 & 6 \\
Junior College & 3 & 0 \\
College & 4 & 4 \\
Masters & 2 & 0 \\
Doctorate & 0 & 0 \\
\hline
\end{tabular}

post-sermon discussion aspects of the project, and have more significant material to share during the church life part of worship. 


\section{CHAPTER TWO}

\section{THE NEW SABBATH SERVICES}

This chapter describes in narrative form the modified, non-traditional Sabbath service as conducted throughout this project. The effects of six changes will be studied in chapters three and four. Though the 9:15 a.m. to 12:00 noon time of the Sabbath program was typical of Seventh-day Adventist services, the worship service preceded Sabbath School because the pastor had responsibilities in two other churches in the district. A great effort was made to keep the following schedule. Worship Service: $9: 15-10: 45$

$$
\begin{aligned}
& \text { 9:15 - 9:45 Contemporary Music \& Church Life } \\
& 9: 45 \text { - 9:55 Prayer Requests \& Needs Prayer } \\
& 9: 55 \text { - 10:20 Life-situational Sermon } \\
& 10: 20 \text { - 10:35 Discussion of Applications } \\
& 10: 35 \text { - 10:45 Dedication, Offering, and Benediction }
\end{aligned}
$$

Sabbath School: 11:00-12:00

$$
\begin{array}{ll}
10: 55-11: 05 & \text { Contemporary Music Song Service } \\
11: 05-11: 25 & \text { Instruction on Needs or Mission Report } \\
11: 25-12: 00 & \text { Sabbath School Lesson }
\end{array}
$$




\section{The Worship Service}

\section{$9: 15-9: 45$ Contemporary}

Music and Church Life

Music (First segment)

For thirty minutes I moderated a fast-moving church-life program. The first three minutes presented taped contemporary religious music as accompaniment for congregational singing--support needed by the small congregation. Because the songs were new, song sheets with words were temporarily inserted into the hymn books.

\section{Interview (Church Life)}

After this singing, guest speakers ${ }^{1}$ were interviewed for seven to ten minutes. This was the longest single segment of the 9:15 to 9:45 part of the service, but the pace was fast.

When no guest speakers were present, I interviewed one or two church members who had been assigned personal ministry projects. An elder and his wife were asked to share ideas on visiting a shut-in. A young mother who was interested in nutrition shared some healthful-living ideas. Two ladies who had attended Alcoholics Anonymous shared their experiences. Another member told of ministering to the victim of a tragedy.

1 Because the pastor served three churches, guest speakers were used six Sabbaths. 
Music (Second Segment)

After the interviews, the congregation sang for another three minutes. During this time some of the songs were from the hymn book rather than from the contemporary music.

\section{Announcements (First Part)}

The announcements were presented in two segments. During the first, the local pastor or elder revealed the purpose of the offering and related other announcements. After the new program was initiated, one of the members explained why she liked the new format. Another Sabbath a young woman who sang well announced the 9:15 time for song service and encouraged members to come and enjoy the music. (This announcement was important because church was starting right on time--fifteen minutes earlier than it had regularly begun.)

Because church services should be fellowshipcentered while also being theocentric, I concluded the first announcement period by having the members and visitors stand and welcome one another with a hug. Sometimes I had members of the congregation stand at their seats and share their reasons for happiness.

Music (Third Segment)

This time of fellowship ended as all sang three hymns praising the name of God, such as, "To God Be The 
Glory," and, "Praise Him! Praise Him!" These songs were selected from the topical index of the hymn book. Usually two stanzas were used and occasionally these did not include the last.

\section{Announcements (Second Part)}

The second announcement period told of future personal ministry interviews, speakers and topics for the coming two Sabbaths, and the most significant event that would occur during the coming month. When possible, these announcements also were conducted as interviews.

\section{Music (Fourth Segment)}

singing hymns of meditation, prayer, faith, and trust focused on the faithfulness, grace, mercy, and love of God, such as, "Tis the Blessed Hour of Prayer," and, "Near to the Heart of God," prepared the congregation for prayer. Occasionally a scripture or responsive reading completed the preparation for prayer and ended the thirty-minute church-life aspect of worship.

\section{9:45 - 9:55 Prayer Requests} and Needs Prayer

On the first Sabbath of each month, the prayer aspect of worship was patterned after one I first saw in the 500-member Omaha, Nebraska, SDA church. In that church, between 60 and 75 percent of the congregation came to the front of the sanctuary and knelt together as. 
three prayers were offered. since $I$ had been so impressed by this fellowship and ministry and by the number of members that participated, I determined to include it in future church services.

In the small church of this project, as much time as needed was given for prayer requests. Usually 50 percent or more of the congregation expressed requests-frequently with deep emotion, which added reverence and urgency to the prayer time. Requests, which covered the full spectrum of needs that might be known to the members of any church, came from members and visitors, adults and children.

After the requests were presented, the procedure of coming to the front for prayer was explained and usually everyone came forward. Before the third prayer ended, participants were invited to place their arms around those near them in a gesture of caring. ${ }^{1} I$ was concerned as to how this action of love would be accepted in the project church, but my fear disappeared during the initial trial. At the conclusion of the prayers, participants helped one another up from their knees. frequently embraced one another again, and wiped tears from their eyes.

${ }^{1}$ The first time someone placed a hand on me in a gesture of caring, I determined to include this ministry. 
On Sabbaths other than the first one each month, people knelt at their seats when prayer was offered. To increase participation, several people offered sentence prayers or a few people offered short prayers. Sometimes several members each offered one specific element of the prayer--praise, thanksgiving, submission, confession, forgiveness, or petition--so that the main prayer became complete as all contributed to the prayer. Occasionally the Lord's Prayer was repeated in unison.

$9: 55-10: 20$ Life-

situational Sermon

The sermon, coming immediately after the morning prayer, was to be life-situational and limited to twenty-five minutes. Prior to commencing the ten-week project, the local pastor scheduled himself to preach two sermons, arranged for a musical group to present a program, and asked a student to present one sermon. For six of the Sabbaths I asked Adventist college teachers and others to present sermons in the areas of their expertise.

Two women from the Home Economics department preached. One, speaking on the religious training of children, told of the developmental tasks children learn at various ages. The second talked about food of the Bible and of modern times, including the idea of Christian hospitality. An Adventist accountant preached 
on Christian standards of finance in the everyday world. A couple accustomed to presenting marriage enrichment seminars presented a sermon on the home.

10:20 - 10:35 Discussion

of Applications

Recognizing the importance of members expressing themselves, I asked each speaker to allow fifteen minutes for a discussion, not about the speaker or the method of presentation, but concerning possible applications of the sermon. Two things stood out about this part of the service: (1) the intense interest of the members and (2) the shortness of the time.

During the discussions, I asked the questions, "What did you hear God say this morning?" "What should we do this week?" "How does this message apply to us?" and "How do we do that?"

10:35 - 10:45 Dedication,

offering and Benediction

The dedication part of the service began as I asked, "Who would like to speak a few words of dedication this morning?" One or two persons would, in turn, speak softly. Occasionally the congregation sang or read in unison the words of a hymn selected from the topics of consecration, loving service, or invitation, matching the text with the message of the morning. The reading, in 
particular, proved to be inspirational to the congregation.

I included in the service of dedication a reminder that the giving of tithes and offerings could be a rededication of one's life to God. The purpose of the offering was restated and prayer was offered. After the offering was collected, the deacons did not return to the front, nor was the "Doxology" sung.

The worship service closed with a brief, appropriate, positive blessing: i.e., "The Lord give you wisdom in training your children. The Lord make you inspirational to them. The Lord be with you now and forever more. Amen."

\section{Sabbath School}

10:55 - 11:05 Contemporary

Music Song Service

Although Sabbath School was scheduled to begin at 11:00, five minutes before the end of the intermission I played taped music at medium volume. When the singing of the contemporary music actually began, the volume of the music was increased so that people could hear the tape.

\section{1:05 - 11:25 Instruction on}

Needs or Mission Report

I felt that after the song service each Sabbath there should be instruction on everyday needs ${ }^{1}$. (This

${ }^{1}$ In mission fields, medical and educational needs are supplied and aid like this is called "lift." 
was replaced once a month by Mission Spotlight.) One Sabbath a South African Adventist couple talked on Christianity and racial problems. Another Sabbath a girl told of her experiences as a foreign exchange student. The guest speakers gave the instruction when they were present.

Having searched local resources, I discovered that personnel from the mental health organization would talk on topics like stress control, aging, alcohol and drugs, personal growth, and coping with loneliness, grief, and depression. People from a christian counseling center would talk on marriage and the family. Two hospitals and the Adult Children of Alcoholics (ACOA) organization also wished to provide speakers. Several groups selected the topic of the sexually abused child.

Because the congregation asked questions, the allocated time seemed too short, but the discussion was stopped at 11:25 to give a full thirty-five minutes for the Sabbath School lesson study.

\section{1:25 - 12:00 Sabbath School}

\section{Lesson Study}

The remainder of Sabbath School was given to the lesson study. It was not uncommon for the study to run till 12:05 p.m., but it was never allowed to run longer than this. 


\section{A Note about Worship Preparation}

More than five hours were needed each week to select not only the song but also the verses with the appropriate message; to arrange, plan, and at times even practice the interviews; and to prepare the announcements for the worship service. This did not include time spent preparing for the sermon. However, since Sabbath is the time that the pastor has influence over the most people, I considered careful preparation essential. When one spends twenty hours to prepare a thirty-minute sermon, it seems to be poor planning to spend only a few minutes preparing the other thirty-minutes of worship.

\section{Choice of Contemporary Music}

As most Adventist churches do not use contemporary religious music in their sabbath services, I shall explain why and how the music was selected.

\section{Reason for Selecting}

Contemporary Music

$$
\text { Prior to this project, while visiting thirty-one }
$$
active, inactive, and former members of the project church, I learned that fifteen thought that church music was slow and lifeless, fourteen wanted it to be more modern, and twenty-four believed more music should be used.

Outside of Sabbath hours, most church members do not listen to hymn tunes, nor do they often listen to 
contemporary religious music, though this type of listening is increasing due to the increase in the number of religious radio stations. of the two types of religious music--contemporary and traditional--contemporary religious music rather than the music of the church hymnal is more similar to the music the members usually listen to. Because the of members' wish for lively church music--the style of music that members usually listen to--and my desire to start worship with things familiar to the congregation, Sabbath services were begun with contemporary religious music.

\section{Method of Selecting}

Contemporary Music

To select the music for the worship service, I went to a religious book store and listened for several hours to religious tapes, some with split track for words and music separation, and others with both on the same track. I found that most of the music would not be acceptable to the project church because the music's emphasis on the rhythm rather than the message would not be conducive to worship. I did select Magnify the Lord, ${ }^{1}$ volumes one and two, which was created for congregational singing and which had a companion song book.

\footnotetext{
${ }^{1}$ (Kansas City, MO: Pilot Point Music, 1986)
} 
Introduction of the

Contemporary Music

During Sabbath School I played a sample of the music and the members liked it immediately; in fact, one family liked it so well they bought a copy of the tape that week. Because the congregation liked the music, it was used for two months prior to and during the project for the Sabbath School song service.

Before introducing contemporary music into the worship service, I asked the church board if they would approve the change. Because the congregation wanted to use the new hymn books, the board initially preferred the use of only these books for the worship service. After some discussion, however, the board decided that a small quantity of the contemporary music could be used for the worship service, but that hymns would provide the majority of the music during the project. 


\section{CHAPTER THREE}

\section{EFFECTS UPON THE CONGREGATION OF THE}

\section{CHANGES IN THE WORSHIP SERVICE}

The purpose of this chapter is to describe the effects which the changes in the Sabbath services-described in chapter 2--had upon the congregation. Chapter 4 discusses the effects in terms of the schutz Measures.

The members of the congregation were asked on four occasions to state their opinions of the project worship services which they had observed. The first statements by the congregation were given on the first Sabbath of the project.

\section{First Sabbath Evaluation}

Directions for completing the evaluation form, the six questions of the form, ${ }^{1}$ and a summary and evaluation of the responses to each question are as follows. ${ }^{2}$

${ }^{1}$ Appendix B contains the six-question evaluation form as used the first Sabbath.

2 While twenty-two attended church and seventeen attended Sabbath school the number staying for lunch is unknown. Thirteen people completed the questionnaire after lunch. 
Directions: Circle the number that best describes your opinions on the 1 to 4 scale, or circle the No Opinion.

1. Did you like this Sabbath service?

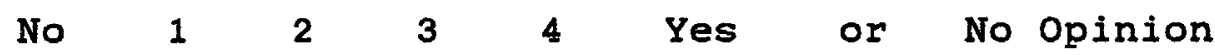

Number of

Responses :

211

On this question, which received the most positive rating of the six questions of this first evaluation, two members of the congregation marked 3 and eleven marked 4 , indicating that the congregation initially liked the changes in the Sabbath service.

2. Did you like the order of the service?

No $\quad \begin{array}{llllll} & 1 & 2 & 3 & 4 & \text { Yes or No Opinion }\end{array}$

Number of

Responses :

49

To this question four people responded with 3 and nine responded with 4. Two responses to this question being marked one number lower than on question 1 would indicate that the congregation was slightly less satisfied with the order of the service than with the service as a whole.

3. Do you dislike or like the new music style?

Dislike $1122 \quad 3 \quad 4$ Like it or No Opinion

Number of

Responses :

$\begin{array}{lll}1 & 3 & 7\end{array}$

2

While ten of the thirteen participants liked the contemporary music, four marked their responses at a 
lower level than for question 1 with one of these disliking the music; two marked "no opinion." Thus the congregation's enjoyment of the music was not as great as I had anticipated. The one respondent who marked dislike for the music at the 1 level wrote that he liked the idea of a song service, but that the music chosen was too fast.

4. Do you dislike or like our new prayer-request time?

Dislike $1 \quad 2 \quad 3 \quad 4 \quad$ Like it or No Opinion Number of Responses : $3 \quad 10$

All of the respondents affirmed their appreciation of the prayer aspect of worship, three responding at the 3 level and ten at the 4 level. As only one participant marked this question at a level lower than on question 1 , I concluded that the prayer request and main prayer time was one of the two most appreciated parts of the service. 5. Do you dislike or like the after-sermon discussions of applications?

Dislike $1 \quad 2 \quad 3 \quad 4$ Like it or No Opinion Number of Responses : 47 2

Eleven of the thirteen respondents liked the after-sermon discussion of applications, four responding at the 3 level and seven at the 4 level; the two remaining respondents expressed "no opinion" on this question. 
While the prayer time was the most-liked aspect of the service, the post-sermon discussion was the second most 1 iked.

6. Would you like to sit in a circle during Sabbath School discussion times rather than in rows?

$$
\text { No } \quad 1 \quad 2 \quad 2 \quad 3 \quad 4 \quad \text { Yes or No Opinion }
$$

Number of

Responses: $\quad 4 \quad 1 \quad 1 \quad 6 \quad 1$

While planning this project I proposed that the congregation sit in a circle for Sabbath School, but because the church board was adverse to this proposal, the idea was dropped from the project. Judging by the survey, a 54 percent majority would have been pleased to sit in a circle. The division of opinion testified to a need for diversity and self-determination even within a small congregation.

\section{Pifth Sabbath Evaluation}

To the preceding six questions, three questions were added for the evaluation that was solicited immediately after church was dismissed on the fifth Sabbath, the midway-point of the project. ${ }^{1}$ All questions were answered by eleven ${ }^{2}$ respondents, and a summary and

${ }^{1}$ Appendix $B$ contains the nine-question evaluation form as used the fifth Sabbath.

2 While seventeen attended church, six neither completed the questionnaire nor stayed for Sabbath School. 
evaluation of the responses to each question are given below.

1. Did you like this Sabbath service?

No $1120 \quad 3 \quad 4 \quad$ Yes or No Opinion

Number of

Responses :

28

1

Whereas after the first Sabbath of the project 85 percent of the respondents affirmed with a 4 that they liked the program, after this service only 73 percent made the same affirmation, and yet all respondents liked the service except for the one who expressed no opinion. Reasons for the decreased enjoyment were revealed in the responses to the next questions.

2. Did you like the order of the service?

No $12 \quad 2 \quad 3 \quad 4$ Yes or No Opinion

Number of

Responses :

38

While 69 percent registered a 4 in response to question 2 the first week, at the midpoint of the project 73 percent registered a 4 response. Thus it appears that approval of the order of service increased slightly over the first five weeks of the project. After the first week of the project when the responses to questions 1 and 2 were compared, it was seen that two respondents marked question 2 one number lower than on question one. After the fifth Sabbath when the responses to questions 1 and 2 were compared, none of the respondents marked their 
responses at a lower number on question 2 , supporting the conclusion that the congregation was enjoying the new order of service more than it had initially.

3. Do you dislike or like the new music style?

Dislike $123(3.5) 4$ Like it or No Opinion

Number of

Responses: $\quad 2 \quad 3 \quad$ (1) $4 \quad 1$

on this question, one person marked the scale at 3.5. For two reasons I concluded that while initially a large portion of the congregation liked the contemporary music, their appreciation diminished slightly as the project continued to midpoint:

1. The percentage of people who said they liked the music dropped from 77 to 73 percent during the five weeks

2. The percentage of people who marked liking the music at level 4 dropped from 70 to 50 percent.

Possible reasons for this decrease in appreciation of the music could be the monotony caused by using only a few selections from the contemporary music tape and the difficulty of the music, which made learning it a slow process. 
4. Do you dislike or like our new prayer-

request time?

Dislike $1 \quad 2 \quad 3 \quad 4$ Like it or No Opinion

Number of

Responses:

110

Initially the prayer time was the most appreciated part of the Sabbath services, being liked at level 4 by 77 percent of the congregation. At the project midpoint, that appreciation increased to 91 percent.

5. Do you dislike or like the after-sermon

discussions of applications?

Dislike $1 \quad 2 \quad 3 \quad 4$ Like it or No Opinion

Number of

Responses:

110

Both initially and at midpoint of the profect the after-sermon discussion was the second-most-liked part of the service. At the project midpoint, level 4 appreciation was expressed by 91 percent of the respondents. The first week 54 percent had expressed approval at the 4 level and 31 percent at the 3 level.

6. Would you like to sit in a circle during Sabbath School discussion times rather than in rows?

$$
\text { No } 11 \quad 2 \quad 3 \quad 4 \quad \text { Yes or No Opinion }
$$

Number of

Responses

51


The desire to sit in a circle during sabbath School decreased from 54 percent of the congregation expressing approval the first week to only 27 percent the fifth week.

The following three questions were not a part of the first survey.

7. If you had the music tape, would you like to listen to it at home during the week?

No $1120 \quad 3 \quad 4 \quad$ Yes or No Opinion

Number of

Responses: $\quad 3 \quad 1 \quad 7$

Feeling at the midpoint of the project that there was opposition to the contemporary music, I wondered if the opposition was directed toward the music or toward its use in church. Since responses to question 7 revealed that two individuals who liked the music in church would not use it at home, I concluded that the dislike was for the contemporary music itself. still, the majority of the congregation liked the use of contemporary music in church.

8. Do you like or dislike the topics that have been presented these past five weeks?

Dislike $1 \quad 2 \quad 3 \quad 4$ Like it or No opinion Number of

Responses :

$\begin{array}{lll}1 & 3 & 6\end{array}$

1 
I also wanted to know if the congregation liked the subject matter of the sermons and instruction. In response to question $8, \quad 82$ percent of the respondents said they liked the topics, 55 percent of the affirmation responses were marked at the 4 level. Two members did not appreciate the topics.

9. Do you feel the services are too secular, not presenting God and his grace and power enough?

No $1142 \quad 3 \quad 4 \quad$ Yes or No Opinion

Number of

Responses:

8

11

1

While 73 percent affirmed that the services were not too secular, 27 percent were unable to make this affirmation. Comparing the responses to questions eight and nine reveals that 9 percent of the congregation enjoyed the topics being presented, but felt they were too secular for worship services.

\section{Seventh Sabbath Evaluation}

As a part of the post-sermon discussion on the seventh Sabbath, members of the congregation were asked to tell their impressions of the services to date and to suggest what should be kept or dropped from the services. Members' wishes that were presented in this discussion about each of the six aspects of the Sabbath services are summarized separately below. 
Contemporary Music

Members of the congregation who spoke without restraint of mildly disliking some of the music because it was hard to sing wished neither to stop using the music nor to intersperse the singing with other activities: but they did desire a shorter song service and more special music. One young person said she missed singing the "Doxology."

\section{Church Life}

Even as there were no strong feelings concerning the music, so the congregation had little preference concerning the church-life aspect of the worship service. The congregation enjoyed the interviews of guest speakers and members, but when members gave talks during the church-life program, the congregation showed decreased interest, revealing the importance of having interviews rather than monologue presentations.

\section{Prayer-Request Time}

The prayer-request time was the change that the congregation most appreciated, as was noted previously. The congregation wanted to continue this aspect of the worship permanently. 


\section{Iife-situational Sermons}

Speaking concerning the life-situational sermons, one usually quiet lady testified that the sermon on child training was just what she needed that week to help her son's family through a crisis! Others also affirmed the value of the sermons. None of the congregation commented that the sermons were too long, too short, or too secular.

\section{Formality of Opening and}

\section{closing Worship}

With strong feelings, members told of missing the formality of the processional, the kneeling for the invocation, and the closing hymn and prayer which typically opened and closed the worship service.

As a result of the views expressed, the processional, kneeling for the invocation, and the closing hymn and prayer were reinstated for the last three Sabbaths of the project to increase the worship formality.

\section{Post-sermon Discussion}

Along with the prayer-request time, the post-sermon discussion was consistently one of the two most appreciated new aspects of worship, and the congregation wished to continue it. Members had often wished 
they could discuss or respond to some point of the sermon; in the new service they could respond.

\section{Sabbath School Discussion}

The members spoke with earnestness when they said that arranging and receiving speakers for this part of the services provided for self-improvement and evangelism. It brought non-Adventists with expertise into the church to contribute to the services and to observe church members, and it took church members into the community to make the invitations. Therefore the members wanted to continue this aspect of the Sabbath services.

\section{Last Sabbath Evaluation}

After the services on the last Sabbath of the project a seventeen-question evaluation form was marked by eight members. ${ }^{1}$ The questions, a summary, and an evaluation of the responses to each question are given below. 2

1. Did the Sabbath services deal with people's needs?

$$
\text { No } 12(2.5) 3 \quad 4 \text { Yes or No Opinion }
$$

Number of

Responses: $1 \quad$ (1) $3 \quad 3$

${ }^{1}$ While thirteen adults attended church, three visitors and two members declined to mark the evaluation form.

${ }^{2}$ Appendix B contains the seventeen question evaluation form as used the last Sabbath of the project. 
To this question 75 percent of the congregation, responding affirmatively, testified to the value of life-situation-oriented sermons and services. The two individuals who responded negatively to this question commented that only more biblical sermons would meet people's needs.

2. Did you prefer the formal or informal worship services?

$$
\text { Formal Informal No Opinion }
$$

Number of

Responses: 6

1

1

Whereas during the seventh-week evaluation the congregation requested that more formality be added to the service, and this request was granted, this question sought to ascertain whether the congregation still preferred the more formal service. Seventy-five percent of the congregation responded affirmatively, confirming the need for formality in the worship service.

3. Did you dislike or like the contemporary music style?

$$
\begin{array}{lllllll}
\text { Dislike } & 1 & 2 & 3 & 4 & \text { Like or No Opinion }
\end{array}
$$

Number of

Responses :

$\begin{array}{llll}2 & 1 & 3 & 2\end{array}$

Whereas the appreciation of the contemporary music dropped steadily the first seven weeks of the project, it was not used for the last three Sabbaths, but song services using selections from the hymnal were 
continued. This question sought to ascertain the feeling of the congregation about the contemporary music after not using it for three weeks. As expected, the percentage of those liking the contemporary music dropped another 10 points to 63 percent.

4. If you had the music tape, would you like to listen to it at home during the week?

No $1120 \quad 3 \quad 4 \quad$ Yes or No Opinion

Number of

Responses: $3 \quad 2 \quad 1 \quad 2$

As at the project midpoint, so at this final evaluation, two individuals who liked the music in church would not use it at home, supporting the conclusion that the dislike was directed toward the music, not toward its use in church. Still, the majority of the congregation liked the use of the contemporary music in church.

5. Circle the times you wish to use the contemporary music:

For Sabbath School For Church Discontinue it Number of Responses : 5 1 3

While 63 percent of the congregation wanted the music to be used for Sabbath School, supporting the conclusion of question 3 , and 12 percent wanted it used for church, 37 percent wanted its use discontinued altogether. 
6. Did you dislike or like our new prayer-request

time?

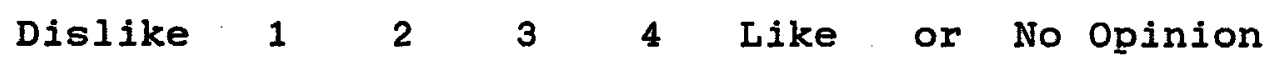

Number of

Responses :

As in the previous evaluations, this and the next question received the most positive affirmation. All but one member of the congregation responding to the question expressed highest appreciation for the prayer time, confirming that this aspect of the worship service should be continued. One person chose not to express an opinton.

7. Did you dislike or like the after-sermon discussions of applications?

$\begin{array}{lllllll}\text { Dislike } & 1 & 2 & 3 & 4 & \text { Like or No Opinion }\end{array}$ Number of

Responses: $1 \quad 7$

While at the project midpoint one participant disliked the after-sermon discussion, this time one person marked the lowest level of approval for this part of the service. All others expressed maximum approval for the discussion suggesting that this opportunity for the congregation to speak should be continued. 
8. Would you dislike or like to sit in a circle during the Sabbath School lesson study rather than in rows?

$$
\text { Dislike } \quad 1 \quad 2 \quad 3 \quad 4 \quad \text { Like or No Opinion }
$$

Number of

Responses:

$6 \quad 1 \quad 1$

Initially 54 percent of the congregation wished to have Sabbath School lesson study while sitting in a circle, but at the project midpoint acceptance dropped to 27 percent. At the end of the project only 12 percent still affirmed this desire. This was probably because, as mentioned by some members, the pews would have to be moved to form the circle. Until additional space is provided in the church, the seating pattern cannot be satisfactorily changed.

9. Did you dislike or like having instruction

before the lesson study?

$$
\begin{array}{lllllll}
\text { Dislike } & 1 & 2 & 3 & 4 & \text { Like or No Opinion }
\end{array}
$$

Number of

Responses :

13

1

While 75 percent of the congregation appreciated having instruction on felt needs during Sabbath School, two individuals opposed the instruction because it was not Bible-centered enough. While concluding that this instruction is needful and appreciated, I recognize that it may cause some harmful alienation. 
10. Did you like or dislike the topics that have been presented the past ten weeks?

$\begin{array}{lllllll}\text { Dislike } & 1 & 2 & 3 & 4 & \text { Like or No Opinion }\end{array}$

Number of

Responses:

125

Whereas at the project midpoint two individuals did not like the topics selected, this time only one person expressed some dislike for them. The last sermon of the project--on Christian ethics as exercised in financial matters--the congregation especially appreciated, stating that more such sermons should be given.

11. Did you feel the services were too secular, not presenting God and His grace and power enough?

No $11 \quad 2 \quad 3 \quad 4 \quad$ Yes or No Opinion

Number of

$\begin{array}{llllll}\text { Responses: } & 2 & 1 & 1 & 3 & 1\end{array}$

While at the project midpoint 73 percent of the congregation said the services were not too secular, this time only 37 affirmed the sacredness of the services. The last sermon presented high ethical standards but said little about the power of God to help people live a moral life. The response may have been a reaction to this lack. Responses to this question should be considered together with the responses to questions 10 and 16 , which affirm the frequent use of life-situational sermons. 
12. Did you dislike or like the time for rededication and testimony at the end of the worship service?

$$
\text { Dislike } \quad \begin{array}{llllll} 
& 2 & 3 & 4 & \text { Like or No Opinion }
\end{array}
$$

Number of

Responses:

$1 \quad 7$

At the conclusion of the post-sermon discussion each week I encouraged the congregation to rededicate their lives to God and gave time for a personal testimony or two. Inasmuch as the responses to this question showed that all of the congregation appreciated this aspect of the service, it should be continued.

13. Did you dislike or like the offering being a part of the final dedication part of the service?

$$
\begin{array}{llllllll}
\text { Dislike } & 1 & 2 & 3 & 4 & \text { Like or No Opinion }
\end{array}
$$

Number of

Responses:

$1 \quad 1 \quad 4$

2

During the dedication aspect of the worship service I connected the giving of offerings with personal dedication and then called for the deacons to collect the offering. While 63 percent of the congregation liked this, two expressed no opinion about it and one was opposed to it. Having the offering at this time appeared to contribute to the act of self-dedication. 
14. Did you dislike or like greeting one another and visitors during announcements?

$$
\begin{array}{lllllll}
\text { Dislike } & 1 & 2 & 3 & 4 & \text { Like or No Opinion }
\end{array}
$$

Number of

Responses :

125

Eighty-seven percent of the congregation appreciated the time when people greeted each other during the church-life aspect of worship. Even though in a small congregation everyone knows everyone else and visitors are quickly spotted, formal greetings like this were still appreciated.

15. Did you dislike or like being encouraged to hug one another during greeting?

$\begin{array}{lllllll}\text { Dislike } & 1 & 2 & 3 & 4 & \text { Like or No Opinion }\end{array}$ Number of Responses: $\quad 2 \quad 2 \quad 4$

Occasionally during the greeting time I encouraged members to greet one another with a friendly hug. Only one person marked the preceding question at level 2, but two individuals marked this question at level 1; therefore it appears that there was more dislike when the greeting became more intimate. 
16. How many times a month would you like a sermon like the ones on child-training, nutrition, finances, and etc.?

$1 \quad 2 \quad 3 \quad 4$

Number of

Responses: $\quad 4 \quad 3 \quad 1$

Responses to this question again show that the congregation appreciated the use of life-situational sermon topics. Half of the congregation wished they could have life-situational sermons once a month, and another 37 percent wished to have them twice a month. If ministers were to preach this type sermon, they would need to make them very Biblical and not preach them more than half of the time.

17. How many times a month would you like to have the post-sermon discussions?

$$
\begin{array}{llll}
1 & 2 & 3 & 4
\end{array}
$$

Number of

Responses: $\quad 1 \quad 2 \quad 1 \quad 4$

While one of the two best-liked aspects of the project worship service has consistently been the aftersermon discussion, the response to this question showed that half of the congregation did not want the discussion every week, but 87 percent wanted it at least twice a month. 


\section{CHAPTER FOUR}

\section{THE SCHUTZ MEASURES}

At the beginning of this study, "Element $R$ (You to Me)" of the Schutz Measures ${ }^{1}$ was given to a total of sixteen active and thirteen inactive members of the project church. On the last Sabbath of the project the instrument was retaken by the twelve members present. 2 This chapter describes the Schutz Measures and presents the members' results on the test. Chapter 5 presents conclusions and recommendations based upon these results.

\section{Description of the Schutz Measures}

The Schutz Measures, a part of an integrated series of instruments for assessing elements of interpersonal relationships, consists of short items answered on a six-point scale ranging from 1 , signifying definitely not true, to 6 , signifying especially true. Each item is answered twice, once describing the way things are perceived and once indicating how the

\section{${ }^{1}$ Hereafter called the Schutz Measures or the} instrument. A copy of the instrument is found in Appendix C.

${ }^{2}$ One of the members who took the test the first time did not care to take the test the second time. Three other members were not present to take the second test. 
respondent would like them to be, for a total of 108 statements. The instrument, which uses a simple vocabulary appropriate for any age from junior high to adult, can be used for pre and post measurements to provide data sensitive to changes in behavior and feeling.

There are six elements in the test: In my opinion, (1) You include me, (2) You control me, (3) You are open with me, (4) You feel that I am significant, (5) You feel that I am competent, (6) You like me. Because participants respond to nine statements for each of the six elements, the scores for each element range from 1 to 9, with 1 signifying strong disagreement with the element statement, i.e., "you never include me," and 9 signifying strong agreement, i.e., "you always include me."

Because the fifty-four statements are responded to first "The Way It Is" and second "The Way I Want It," the score (1 to 9) of the second can be subtracted from that of the first to arrive at a minus 9 to plus 9 scale. This scale is useful for making definitive satisfaction and evolution statements about the element, i.e., positive values: "You include me more than I want you to." or negative values: "I want you to include me more than I feel that you do." 


\section{Reliability of the Instrument}

Mean reproducibility for the "The Way It Is" and "The Way I Want It" aspects of the instrument are 95 and 92, respectively, with "I want you to control me" scoring lowest at 89 and "You like me" scoring highest at 99. The $\mathrm{N}$ value for the test is 100 .

\section{Effects of the Ten Worship Services upon the Six Elements of the Instrument and the Conclusions of Each Element}

The average scores of the behaviors and feelings for the twenty-nine church members are presented in tables 4 through 9 below. "Averages 1" are those of the instrument taken before the project, "Averages 2 " those taken at the project's end; "Change" is the difference between the initial and final averages for the element; and "Percent" is 100 times the change divided by the range (either 9 or 18 ) of possible scores.

\section{Inclusion}

Table 4 shows the degrees to which members felt and wanted to feel included in church activities. The numerical difference between these two scores-subtracting the score for desire from the score for perception--indicates the intensity of their desire for inclusion. 
TABLE 4

MEASUREMENT OF INCLUSION

The Way It Is

The Way I Want It

Difference

Active Members

\begin{tabular}{llrr} 
Average $1 *$ & 4.13 & 5.38 & -1.25 \\
Average $2 * *$ & 4.83 & 6.50 & -1.67 \\
Change & 0.70 & 1.12 & -0.42 \\
Percent & 7.7 & 12.4 & 2.3 \\
& & Inactive Member & -2.38 \\
Average*** & 2.69 & 5.08 & -9 to 9 \\
Range & $0-9$ & $0-9$ & \\
\hline
\end{tabular}

In the first column, low averages indicate exclusion and high averages indicate inclusion.

In the second column, low averages indicate desire for exclusion and high averages indicate desire for inclusion.

In the third column, low or more negative averages indicate desire for more inclusion and high or positive numbers indicate a desire for more privacy.

*Population variances were: $3.48,3.48$, and 3.94

Standard deviations were: $1.87,1.87$, and 1.98

**Population variances were: $5.97,3.92$, and 4.39

Standard deviations were: $2.44,1.98$, and 2.09

***Population variances were: $3.29,3.92$, and 5.01

Standard deviations were: $1.81,1.98$, and 2.24 
While inactive members felt more excluded and did not desire as much inclusion as active members did, the intensity of their desire to be included was almost twice as great as that of active members. 1

If the pre- and post-test averages for active members are compared, table 4 also shows that the feeling of inclusion increased an average of 7.7 percent, the desire for inclusion increased by 12.4 percent, and the difference between what they felt and what they desired indicated the intensity of their desire for more inclusion was 2.3 percent greater than before the project. To state the same thing another way, after the project they felt and desired less exclusion.

From these figures it seems obvious that if changes like those of this project were to continue, congregation satisfaction would improve and if the inactive members were to become aware of the improvements, their satisfaction would probably also improve.

\section{Control}

Table 5 shows the degree to which members felt and wanted to feel controlled in church activities. The intensity of their desire for control or freedom is discovered by subtracting the score for desire from the score for feeling.

${ }^{1}$ See p. 14 for a statement of an expectation of this result. 
TABLE 5

MEASUREMENT OF CONTROL

Active Members

\begin{tabular}{lrrr} 
Average $1 *$ & 5.75 & 5.88 & -0.13 \\
Averages 2** & 5.50 & 5.25 & 0.25 \\
Change & -0.25 & -0.63 & 0.38 \\
Percent & 2.8 & Inactive Members & 2.1 \\
Average*** & 6.31 & 6.31 & 0.00 \\
Range & $0-9$ & $0-9$ & -9 to 9 \\
\hline
\end{tabular}

In the first column, low averages indicate freedom from control and high averages indicate dominance.

In the second column, low averages indicate desire for freedom and high averages indicate desire for control.

In the third column, low or more negative averages indicate desire for more control and high or positive numbers indicate a desire for more freedom.

\footnotetext{
*Population variances were: 4.06, 2.61, 1.73

Standard deviations were: $2.02,1.62$, and 1.32

**Population variances were: $1.25,2.35$, and 1.02

Standard deviations were: $1.12,1.53$, and 1.01

***Population variances were: $3.29,2.52$, and 1.69

Standard deviations were: $1.81,1.59$, and 1.30
} 
While active members initially felt that the church controlled and restrictioned them and that greater control should be exercised, inactive members felt more strongly that the church controlled them, ${ }^{1}$ but they were satisfied with the balance between control and freedom. ${ }^{2}$ After the project, active members felt 2.8 percent freer of controls, wanted 7.0 percent more freedom, and the difference between what they felt and what they desired indicated the intensity of the desire for greater freedom was 2.1 percent higher than before the project.

The six changes to Sabbath services instituted in this project which produce the results seen in table 5 should improve the congregation's satisfaction with their freedom and should be appealing to the inactive members.

\section{Openness}

The last of the feelings is openness. Table 6 reveals that initially all members desired more openness, but the intensity of that desire was nearly twice as strong in the inactive as in the active members. Since Schutz mentions that the desire for contact and openness is usually high in people under age twenty and decreases

${ }^{1}$ See $p .15$ for a statement of an expectation of this result.

2 It should be noted that members have expressed that the greater control should be that of God, not men. 
TABLE 6

MEASUREMENT OF OPENNESS

Active Members

$\begin{array}{lccr}\text { Average } 1 * & 3.75 & 4.63 & -0.88 \\ \text { Averages } 2 * * & 2.75 & 3.75 & -1.00 \\ \text { Change } & -1.00 & -0.88 & -0.12 \\ \text { Percent } & 11.1 & 9.8 & 0.7\end{array}$

Inactive Members

$\begin{array}{llll}\text { Average***} & 3.08 & 4.77 & -1.69 \\ \text { Range } & 0-9 & 0-9 & -9 \text { to } 9\end{array}$

In the first column, low averages indicate lack of openness and high averages indicate openness.

In the second column, low averages indicate desire for privacy and high averages indicate desire for openness.

In the third column, low or more negative averages indicate desire for more openness and high or positive numbers indicate a desire for more privacy.

*Population variances were: $3.44,2.86$, and 6.11

Standard deviations were: $1.85,1.69$, and 2.47

**Population variances were: $0.85,1.19$, and 1.83

Standard deviations were: $0.92,1.09$, and 1.35

***Population variances were: $2.99,2.95$, and 2.21

Standard deviations were: $1.73,1.72$, and 1.49 
only slightly to age thirty-nine, ${ }^{1}$ and because of the large number of young members in the church, especially in the group of inactive members, the desire for greater openness was expected. 2

A comparison of the pre- and post-test averages for active members reveals that while there was a 11.1 percent movement toward feelings of privacy, and the desire for openness decreased by 9.8 percent, the difference indicated that they had a 0.7 percent more intense desire to be more open. It should be noted, though, that the dividing line between privacy and openness is 4.5. While initially the desires of both groups were just barely on the side of the scale indicating a need for more openness, after the project, active members were on the side indicating a need for more privacy ${ }^{3}$. This lowering of the scores into the range of more privacy may have been caused by the increased use of personal testimony or it may have been caused merely by the instability due to change. Whatever the cause, if the active members withdraw to more privacy, the inactive members will be less likely to

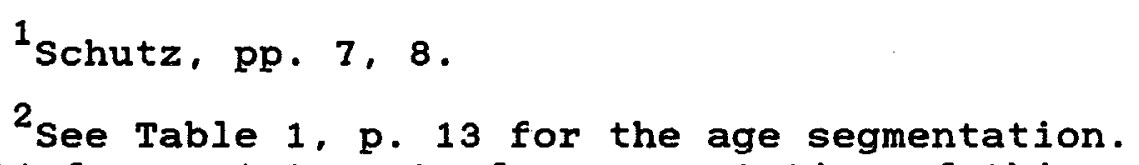
See p. 14 for a statement of an expectation of this result.

${ }^{3}$ This explains the apparent reticents of some members to share their personal experiences in a small group. 
attend church; but if the younger members exercise more leadership in the church and increase the openness of dialogue, the inactive members will most likely take more interest.

\section{Significance}

We turn now to the feeling elements. Most people want to have positive feelings about others and want others to feel good about them. ${ }^{1}$ Table 7 shows the degree to which members felt and wanted to feel significant in the church. These figures indicate that while inactive members placed themselves low on the scale of significance, rating themselves at less than one-third the value at which active members rated themselves, their desire for significance is only slightly lower, making the intensity of their desire for greater importance more than three times that of active members.

A comparison of the pre- and post-test averages for active members reveals that while there was a 6.4 percent movement toward feelings of significance, and while the desire for significance increased by 3.4 percent because a need had been filled, the difference indicates that the intensity of the need to be more significant decreased by 1.5 percent. The project met the need of the congregation to feel significant

$$
{ }^{1} \text { Ibid. , p. } 9 \text {. }
$$


Table 7

MEASUREMENT OF SIGNIFICANCE

Active Members

$\begin{array}{llll}\text { Average } 1 * & 3.50 & 4.19 & -0.69 \\ \text { Averages } 2 * * & 4.08 & 4.50 & -0.42 \\ \text { Change } & 0.58 & 0.31 & 0.27 \\ \text { Percent } & 6.4 & 3.4 & 1.5\end{array}$

Inactive Members
Average***
1.15
3.38
$-2.23$
Range
$0-9$
$0-9$
-9 to 9

In the first column, low averages indicate lack of feelings of importance and high averages indicate feelings of importance.

In the second column, low averages indicate "I do not want you to feel I am important" and high averages indicate "I want you to feel I am important".

In the third column, low or more negative averages indicate desire for more feelings of significance and high or positive numbers indicate there are too many feelings of significance.

*Population variances were: $5.75,6.78$, and 8.71 Standard deviations were: $2.40,2.60$, and 2.95

**Population variances were: $7.58,8.25$, and 2.91

Standard deviations were: $2.75,2.87$, and 1.71

***Population variances were: $1.21,3.01$, and 5.56

standard deviations were: $1.10,1.73$, and 2.36 
through involving them in the services and discussing things important to them, so that when the project was finished, the members believed they were more significant individuals.

\section{Competence}

From table 8 we see that inactive members did not feel but wished to feel as esteemed for their competence as active members, and the intensity of that desire was almost twice as strong.

If the pre- and post-test averages for active members are compared, we see that while there was a 3.4 percent movement toward feelings of competence, and the desire for competence increased by 2.8 percent, the difference indicates they had a 3.3 percent less intense desire to be more competent. To state it another way, involving the members in interviews and discussions during the project apparently helped the congregation to feel slightly more competent. I would expect that continuing the interviews and discussions for additional weeks would lessen feelings of incompetence but would not erase them quickly. 
TABLE 8

MEASUREMENT OF COMPETENCE

Active Members

$\begin{array}{lccc}\text { Average } 1 * & 3.19 & 4.75 & -1.56 \\ \text { Averages } 2 * * & 3.50 & 5.00 & -1.50 \\ \text { Change } & 0.31 & 0.25 & 0.6 \\ \text { Percent } & 3.4 & 2.8 & 3.3\end{array}$

Inactive Members

Average***

Range
1.38

$0-9$
4.38

$0-9$
$-3.00$

-9 to 9

In the first column, low averages indicate feelings of incompetence and high averages indicate feelings of competence.

In the second column, low averages indicate "I do not want you to feel that I am competent" and high averages indicate desire for feelings of competence.

In the third column, low or more negative averages indicate desire for more competence and high or positive numbers indicate a desire for less feelings of competence.

* Population variances were: 5.90, 5.31, and 9.37

Standard deviations were: $2.43,2.30$, and 3.06

**Population variances were: $11.08,7.00$, and 5.25

Standard deviations were: $3.33,2.65$, and 2.29

***Population variances were: $2.24,4.08$, and 4.46

standard deviations were: $1.50,2.02$, and 2.11 


\section{Likabiliby}

Table 9 gives the scores for likability. It is significant that, except for some of the scores for the control element, these scores are the highest of all elements on the instrument and that they corroborate the feelings I discerned in my visitation: members of this church conveyed much love toward one another and yet they desired to be liked more than they were. While inactive members scored themselves below the 4.5 dividing Iine between unloved and loved, that score is at least 35 percent higher than all other low-scoring elements, indicating that the inactive members felt more loved than they felt the other five elements--inclusion, significance, etc.

If the pre- and post-test averages for active members are compared, it is seen that while there was a 6.2 percent movement toward feelings of being loved, and toward the desire for warmth, the lack of a difference indicates that the intensity of desire to be more loved remained unchanged. 
TABLE 9

MEASUREMENT OF LIKABILITY

Active Members
Average 1 *
5.19
5.94
$-0.75$
Averages 2**
5.75
6.50
$-0.75$
Change
0.56
0.56
0.00
Percent
6.2
6.2
0.0

Inactive Members
Average***
4.15
5.08
$-0.92$
Range
$0-9$
$0-9$
-9 to 9

In the first column, low averages indicate dislike and distance and high averages indicate love and warmth.

In the second column, low averages indicate desire for less love and high averages indicate desire for love.

In the third column, low or more negative averages indicate desire for more love and high or positive numbers indicate too much love.

*Population variances were: 4.40, 4.18, and 6.31

Standard deviations were: $2.10,2.05$, and 2.51

**Population variances were: $5.02,5.25$, and 4.69

Standard deviations were: $2.24,2.29$, and 2.17

***Population variances were: $5.51,6.38$, and 8.69

Standard deviations were: $2.35,2.53$, and 2.95 


\section{CHAPTER RIVE}

\section{EVALUATION OF THE PROJECT IN THE LIGHT \\ OF THE THEOLOGY AND HISTORY OF \\ THE PRACTICE OF WORSHIP}

Even though the purpose of this report was not to make an extensive study of the theology and history of the practice of worship, it seemed appropriate in this chapter to make some evaluation of the project in their context.

\section{Historical Knowledge Needed}

The Methodist professor James White speaks of freedom in reformatting worship services, a freedom which is guided by the knowledge of what has been done and learned in the past. He says:

'You are free--if. You are free--if you know what is essential in any type of worship.' The opposite of that is just as true. If you do not know what is essential in any type of worship, then you are completely captive. . . Many clergy and worship-commission members are not at all sure just what is essential as they plan for most types of worship. So they play it safe; they do it the way they have always done it. That may be the dullest and least imaginative way possible, but it involves no risks. We are, then, 
captive to the familiar unless we have a secure base camp from which to explore the unfamiliar.

Robert Webber points out that,

The antihistorical bias of many Evangelicals has led to a prideful rejection of the past among some pastors and leaders. The problem with this attitude is that the rejection of historical perspective imprisons a movement within its present culture. This imprisonment results in the uninformed normalizing of the present moment in history, fogether with all of its aberrations and shortcomings.

\section{Five Essential Elements of Worship and an Evaluation of the Use of Each During the Project}

Two actions inspire worship: man's remembrance of God's activities and God's self-revelation. 3 Expositors of each activity have clarified six essential elements of worship: (1) remembering and reliving experiences with God, (2) God's Self-giving, (3) adoration, (4) reverence, (5) fellowship, and (6) dedication to service. I begin with the element of remembrance.

\section{Remembering and Reliving}

Remembering the greatness of God by reliving past experiences is one essential of worship. The Psalmist declares :

${ }^{1}$ James White, Christian Worship In Transition (Nashville: Abingdon, 1976) p. 10.

${ }^{2}$ Robert Webber Worship $01 d$ and New (Grand Rapids, MI : Zondervan Publishing House, 1982) p. 12.

3. White, pp 32,38 . 
o give thanks to the Lord, call on his name, make known his deeds among the peoples!

sing to him, sing praises to him, tell of all his wonderful works!

Remember the wonderful works that he has done, his miracles, and the judgments he uttered, o offspring of Abraham his servant, sons of Jacob, his chosen ones!

And again the Psalmist says:

o give thanks to the Lord of lords, for his steadfast love endures for ever;

to him who alone does great wonders, for his steadfast love endures forever:

to him who by understanding made the heavens. . .

to him who smote the first-born of Egypt. . .

to him who divided the Red Sea in sunder. . .

to him who smote great kings. .

o give thanks to the Gog of heaven, for his steadfast love endures forever.

Concerning the remembering, reliving, aspect of worship, Robert Webber says,

Worship connects me with the past, gives meaning to the present, and inspires hope for the future as my soul and spirit become blended again into 3 the drama of Christ's life, death, and resurrection.

Webber calls this aspect of worship celebration.

On the way we remember such occasions as anniversaries

and birthdays, he states,

We usually plan well and take great care in preparing for our celebrations by creating symbols generally identified with the particular occasion. For example, we may use our finest silverware and china, and eat in a seldom-used dinning room lighted

${ }^{1}$ PS $105: 1-6$. RSV.

${ }^{2}$ Ps 136 . RSV

${ }^{3}$ Robert Webber, Worship Is a Verb (Waco, TX:

Word Books Publisher, 1985) p. 29. 
only by candlelight. . all enlivened by reminiscences from the past and the sharing of dreams for the future.

Webber continues by comparing worship to celebration.

Worship is in many ways like these festivities because it brings the past into the present by telling and acting out the work of christ. It contains all the elements of festivity: coming together, story, symbol, memory, sharing, relationship, good will, giving, receiving.

Thus an essential element of worship is the remembrance of what God has done for our fathers and ourselves.

During the ten-week project, each life-situational sermon related experiences with God from Bible times, i.e., the talk on food began with God as the giver of the best food in the beginning and with the use of food by the children of Israel in their worship of God. The post-sermon discussion solicited testimonies from attendees of God's actions in their lives that were illustrations of the current sermon. The music sung, particularly the contemporary songs, told of God's help in times of personal crises. These activities helped the congregation to worship God by reliving past experiences in which God was involved.

$$
{ }^{1} \text { Ibid., p. } 28,29
$$


God's Self-Giving

Worship not only involves man's remembrance of God, it also includes God's self-disclosure. Creation, the Exodus, Bethlehem, and the cross are well-known examples of God revealing himself, but He also gave himself in smaller ways. God presented himself to Abraham, Gideon, Zechariah, and John the beloved ${ }^{1}$. Each of these self-givings of God inspired the response of worship in man.

James White brings the gift of God down to our own times when he says: "Preaching is a fresh event through which God gives himself to us again and again." 2

It is common practice to refer to the mercy and grace of God given to us, but I agree with James White that this terminology at times confuses the reality of God's gift. God has and continues to give himself to mankind. White continues,

I prefer to speak of God as giving himself to us rather than to follow convention in speaking of this act as grace. I am not denying that the sacraments contain and confer grace. I am stating, rather, that the use of the human analogy of self-giving seems easier to grasp than grace, which has no immediate human counterpart. Furthermore, it seems better to speak of this self-giving as direct action between God and humanity rather than to introduce $a$ third entity--grace--to this relationship. I am concerned to speak of what happens in the sacraments as dynamic

${ }^{1}$ Gen $12: 1-3,7 ; 13: 14-18 ; 15: 1-21 ;$ Judg $6: 11-24 ;$

Luke 1:8-20; Rev 1:9-18.

2 James white, p. 43 . 
action rather than as a static category, as grace sometimes seems to appear in theological discussions. God gives himself to us in the sacraments just as we give ourselves to others by yarious sign-acts. only he has so much more to give.

God reveals himself through the spoken and written word, through symbols like the Lord's supper, through nature, and through providence. But unfortunately congregations often do not realize this revelation of God. Robert Webber, after telling of a new experience that came to him, says he now wants people to leave church with a "conscious awareness of God."

I have discovered a whole new dimension in worship. I have experienced what I call 'worship from above.' In worship God is speaking and acting, bringing to me the benefits of redemption. Through worship, God works on my behalf. He repairs and renews my relationship with him.

I believe the project congregation became aware of the presence of God as they sang hymns in praise of Him, as the church leaders entered and bowed in prayer, and as the speakers gave God's counsel. Occasionally prayer requests were taken to God in prayer one-at-atime. This one-to-one prayer technique I felt especially helped the congregation to sense the immediate presence of God. The same feeling was also realized as the congregation observed the reverence that filled the

\footnotetext{
${ }^{1}$ White, p. 48 .

${ }^{2}$ Webber, Worship Is a Verb, pp. $18,19$.
} 
sanctuary as members gave testimonies and expressed their rededication to God.

\section{Adoration}

That God is to be praised is assumed or commanded frequently in the Psalms.

Praise the Lord

I will extol the Lord with all my heart in the council of the upright and in the assembly. Great are the works of the Lord they are pondered by all who delight in them ${ }_{1}$ Glorious and majestic are his deeds forever.

Praise the Lord.

Praise, O servants of the Lord, praise the name of the Lord.

Let the name of the Lord be praised, both now and forever more.

From the rising of the sun

to the place where it sets, the name of the Lord is to be praised.

The Lord is exalted over all the nations, $h$ is glory above the heavens.

Other songs of praise include the praise of God by Melchizedek, ${ }^{3}$ the songs of Moses, Deborah and Barak, Hannah, Isaiah, Jeremiah ${ }^{4}$, and of course the hymns of praise in Revelation.

$$
\begin{aligned}
& { }^{1} \text { Ps } 111: 1-3 . \\
& { }^{2} \text { Ps } 113: 1-4 . \\
& { }^{3} \text { Gen } 14: 20
\end{aligned}
$$

${ }^{4}$ Exod $15: 1-18 ; 32: 1-43 ;$ Judg $5: 1-31 ; 1$ Sam $2: 1-11$. Isa $26: 1-6 ; 42: 1-4 ; 50: 4-11 ;$ Jer $20: 13 ; 31: 7-9$. 
Engel and Norton express their views of adoration and praise in worship this way:

Worship. . quite frankly, is often misunderstood and misused by the church. The typical 11:00 A.M. worship service is a curious phenomenon. While formats vary, most follow this kind of pattern: announcements, hymn, scripture reading, prayer, hymn, collection, special music, sermon, and benediction, followed by the exodus. What is it about this type of service that warrants use of the word "worship"? One of the authors asked this question for many years and finally came to the conclusion that what most of us call worship is nothing more than lecture with hymns! This seems to be a far cry from the practices of the old Testament saints. . . .

True Worship was a joyous occasion of giving united praise to God, focusing on his attributes, raising one voice of adoration for his greatness. It is an occasion for the Body of Christ to communicate with God collectively and to acknowledge his deity.

Whatever the case, worship is communication from God's people to him, and its rightful function must not be ignored.

During the ten-week project, adoration of God was sung by the congregation during the worship hymns just before the main morning prayer and at the close of the worship service and was spoken as individuals gave their testimonies about God's actions in their Iives. Adoration is an essential element of true worship.

\section{Reverence}

There is a tension that exists in worship between being reverent in the presence of God and having fellowship within the church community. This is the tension between Theocentric and fellowship-centered

${ }^{1}$ Engel and Norton, pp. 138,139. 
worship. The next section deals with the fellowship aspect of worship. Here we note the awareness of and reverence for the infinite God as an essential part of worship.

At Mt. Sinai when God spoke his law to the children of Israel, he taught Israel reverence. His directions to Moses were:

Assemble the people before me to hear my words so that they may learn to revere me as long as they $f^{i v e}$ in the land and may teach them to their children.

When God gave counsel concerning rejecting the messages of false prophets, he said,

It is the Lord your God you must follow, him you must revere. Keep his commanqiments and obey him; serve him and hold fast to him.

The Psalmist says,

You who fear the Lord, praise him!

All you descendants of Jacob, honor him!

Revere him, all you descendents of Israel

Let all the earth fear the Lord;

let all the people of the world revere him. ${ }^{3}$

Whereas we are to worship God in reverence, Webber talks about a secularization that has crept into many worship services, a familiarity that is inappropriate in the presence of God. He says:

\footnotetext{
${ }^{1}$ Deut $4: 10$.

2 Deut $13: 4$.

${ }^{3}$ Ps $22: 23 ; 33: 8$.
} 
I can remember times in my life when I've experienced the mystery--the awe and reverence-of the woods, or of the desert, or of a snow-capped mountain far above the timber line, a sense of the creation "telling the glory of God" (Ps. 19:1). But, unfortunately, we seldom experience awe and reverence in our churches. All too often the atmosphere seems to work against reverence. Our churches are characterized by a feeling of over-familiarity, an inappropriateness in the approach to God. The sense of transcendence and the otherness and holiness of God seems to be ${ }_{1}$ issing. A kind of secularization has taken place.

White also speaks about this secularization. He points out that while the announcements and other concerns of daily life are important to worship, the emphasis should be upon God--that God is the helper of mankind, and that man's service is a sacrifice to God.

We are not free to turn worship into a pep rally, no matter how splendid the cause. It is unfortunate when the concerns of the church degenerate into a recruitment period. That is a short-term, one-shot approach to relevance. The long-term approach offers these same concerns-where people are hurting and rejoicing--as prayers to God and offers our service to others as a sacrifice before him. The focus in worship should be not on what we do but upon God's doing, even though he may use us in the process.

Webber also points out that churches often have

failed to present God in their music. He says,

Secularization has permeated the church. . . in our music. Many of our contemporary popular songs are not directed to God, nor do they glory in the cross of Christ. Rather, they concentrate on personal experience and self-realization. . . . Our

${ }^{1}$ Webber, Worship Is a Verb, pp. 15,16 .

${ }^{2} \mathrm{~J}$. White, p. 16 . 

religion has followed the curvature of a
self-centered culture.

The communion service is another area where the awareness of the majesty of God has been lost. The American culture is so verbally-linguistically oriented that we often miss the non-verbal communications of God. The Lord's Supper and the ordinance of humility are major symbols. Unless we focus on the non-verbals, we miss much of the message of God. Again Webber speaks.

The mystery also seems to be gone from the Communion Table. . . . [There is] a failure to grasp the transcendent nature of this sign.

In fact, we pay little attention to how God communicates to us through signs and symbols that reach down into the very depths of our being and touch us where words cannot go. As we have worshiped at the altar of "realism," we have. . .neglected the power of our God-given imaginations and the role of the senses as vehicles through which God can communicate to us and we with him.

As God gave himself to the church, probably reverence in his presence was the part of the project that fell the shortest of reaching God's ideal. In an effort to meet man where he was and to minister to him there, reverence may not have been observed as it should have been. When in the seventh week of the project the congregation indicated that they wanted more formality, they were feeling that God was not being reverenced sufficiently. When the formal entry of the elders was

${ }^{1}$ Webber, Worship Is a Verb, pp. 16, 17 .

2 Ibid. , pp. 17 . 
reinstated, when the leaders entered and knelt to pray, the congregation bowed their heads in prayer too and again felt the reverence they desired. Probably the greatest reverence was inspired and seen when, in the dedication, the members gave their testimonies and pledged their service to God.

\section{Fellowship}

Man is a social being, and God desires worship to be a corporate experience. That which parents learn of God they are to pass on to succeeding generations. This is expressed in Ps 78 .

Give ear, o my people, to my teaching; incline your ears to the words of my mouth!

I will open my mouth in a parable; I will utter dark sayings from of old,

things that we have heard and known, that our fathers have told us.

We will not hide them from their children, but tell to the coming generation

the glorious deeds of the Lord, and his might, and his wonders which he has wrought.

He established a testimony in Jacob, and appointed a law in Israel,

which he commanded our fathers to teach to their children;

that the next generation might know them the children yet unborn, and arise and tell them to their children, so that they should set their hope in God, and not forget the works of God, but keep his commandments;

and that they should not be like their fathers, a stubborn and rebellious generation,

a generation whose heart was not steadfast whose spirit was not faithful to God.

$$
{ }^{1} \text { PS } 78: 1-8 \text { (RSV). }
$$


Moses' instruction to Israel concerning family

responsibilities was this:

You shall therefore lay up these words of mine in your heart and in your soul; and you shall bind them as a sign upon your hand, and they shall be as frontlets between your eyes. And you shall teach them to your children, talking of them when you are sitting in your house, and when you are walking by the way, and when you lie down, and when you rise. And you shall write them upon the doorposts of your house and upon your gates that your days and the days of your children may be multiplied in the land which the Lord swore to your fathers to give them, as long as the heavens are above the earth.

Ellen White says concerning our social-religious responsibility,

Parents who have neglected their God-given responsibilities must meet the neglect in the judgment. The Lord will then inquire, 'Where are the children that I gave you to train for Me?"2

Often Americans think of families as the immediate household of father, mother, and children. But other nationalities recognize that the family also includes siblings' families as well as families of the parents' siblings. In the church, the family extends even further. Jesus said,

'Who is my mother, and who are my brothers?' Pointing to his disciples, he said, 'Here are my mother and my brothers. For whoever does the will of my Fatheुr in heaven is my brother and sister and mother.

${ }^{1}$ Deut 11:18-21 (RSV).

2Ellen White, Child Guidance (Nashville, TN: Southern Publishing Association, 1954), p. 561.

${ }^{3}$ Matt $12: 48-50$. 
No wonder James White says,

The sacraments, like preaching, are social acts, usually performed in community and always relating to the community. Thus a private baptism, though valid, is clouded and untrue to its nature in that it does not help members of the community recall their own baptism, nor does it present them an opportunity to commit themselves to the nurture of the new member of the body. . . . Private ordination would be a travesty.

The sacraments are social acts in which God relates to the Christian community and members of it relate to God and to one another by acquiring new roles or in recovering old roles. Thus each sacrament has at its heart relationships between individuals, between individuals and community, and between individuals and God in community.

But as we look at the Christian church, and its worship services in particular, do we see the church acting in community, for the community?

The book of Acts unfolds an exciting story of the church of the first century. All things were mutually shared, deep intimate fellowship was sought, and Christians developed a true sense of community that was characterized by love and acceptance. What about the church today?

Most of us recognize the importance of fellowship. What we mean by this, however, is often a far cry from the New Testament pattern. We seem to have fallen into a non-demanding social relationship and use it as the standard. What has happened to that kind of love within the church whereby we would "lay down our lives for the brethren" (1 John 3:16)?

The project church endeavored to strengthen this commitment to one another during the prayer-request time. Members became aware of and concerned for each other on Sabbath and throughout the week. Thus when one member

\footnotetext{
${ }^{1} \mathrm{~J}$. White, p. 44 .

2 Engel and Norton, pp. 141, 142 .
} 
requested prayer for her unconverted husband because he was feeling the need to quit smoking, another member suggested that the church have a day of fasting and prayer for him. Tangible evidence that the members became more loving and concern for each other has already been seen in the results of the Schutz measures.

\section{Dedication to Service}

John the Revelator, in his depiction of events involving God's church of the last days, heard an angel in the heavens speak of worship saying,

'Fear God and give him glory, because the hour of
his judgment has come. Worship him who made the
heavens, the earth, the sea and the springs of
water.' We worship God because he is our creator. Thus are the Sabbath and creation connected in the fourth commandment :

Remember the Sabbath day by keeping it holy. Six days you shall labor and do all your work, but the seventh day is a Sabbath to the Lord your God. On it you shall not do any work. . . For in six days the Lord made the heavens and the earth, the sea, and all that is in them, but he rested on the seventh day. Therefore the Lord blessed the Sabbath day and made it holy.

Inasmuch as the Seventh-day Sabbath is the memorial of creation, $J$. N. Andrews says,

\footnotetext{
${ }^{1} \operatorname{Rev} 14: 7$.

2 Exod $20: 8-11$.
} 
The importance of the Sabbath as a memorial of creation is that it keeps ever present the true reason why worship is due to God. . . . The Sabbath, therefore, lies at the very foundation of divine worship: for it teaches this great truth in the most impressive manner, and no other institution does this. The true ground of divine worship, not of that on the seventh day merely, but of all worship, is found in the distinction between the creator and $H$ is creatures. This great fact can never become obsolete, and must never be forgotten.

Ellen G. White connects obedience to worshiping

the Creator when she says,

Without obedience to His commandments, no worship can be pleasing to God. 'This is the love of God, that we keep $H$ is commandments.' 1 John 5:3. 'He that turneth away his ear from hearing the lay, even his prayer shall be abomination.' Prov 28:9.

Again Mrs. White connects reverence and obedience

in her counsel to parents training their young:

Let children be shown that true reverence is revealed by obedience. God has commanded nothing that is unessential, and there is no other way of manifesting reverence so pleasing to $\mathrm{Him}$ as by obedience to that which He has spoken.

Solomon in his conclusion says,

Now all has been heard;

here is the conclusion of the matter:

Fear God and keep his commandments,

for this is the whole duty of man.

For God will bring every deed into judgment,

including every hidden thing,

whether it is good or evil.

${ }^{1} \mathrm{~J}$. N. Andrews, History of the Sabbath, chapter 27. Cited by Ellen G. White, The Great Controversy (Mountain View, CA: Pacific Press Publishing Association, 1911), p. 437-8

${ }^{2}$ Great Controversy, p. 436

${ }^{3}$ Ellen G. White, Counsels to Parents, Teachers, and students (Mountain View, CA: Pacific Press Publishing Association, 1913), p. 111 . 
In Isa 58:6-7 God has made known his desire concerning the service which is true worship.

Is not this the kind of fasting I have chosen:

to loose the chains of injustice and untie the cords of the yoke, to set the oppressed free and break every yoke?

Is it not to share your food with the hungry and to provide the poor wanderer with shelter-when you see the naked, to clothe him, and not to turn away from your own flesh and blood?

Commenting on this passage Ellen White says,

Not in idle mourning, in mere bodily humiliation and multitudinous sacrifices, is the true spirit of devotion manifested, but it is shown in the surrender of self in willing service to God and man.

In the parable of the sheep and the goats Jesus said "Whatever you did for one of the least of these brothers of mine, you did for me." 2 After quoting from this parable, Mrs. White says,

To become a toiler, to continue patiently in well-doing which calls for self-denying labor, is a glorious work, which Heaven smiles upon.

And then connecting this service with worship, she continues,

Faithful work is more acceptable to God than the most zealous and thought-to-be holiest worship. It is working together with christ that is true worship. Prayers, exhortation, and talk are cheap fruits, which are frequently tied on: but fruits that are manifested in good works, in caring for the needy,

${ }^{1}$ E. G. White, Desire of Ages, p. 278 .

${ }^{2}$ Matt $25: 40$. 

the fatherless, and widows, are,genuine fruits, and
grow naturally upon a good tree.

Worship is pleasing to God when it comes from one who is a servant of his fellowman in obedience to God. During the project the last act of each worship was a dedication service. During this time one or two individuals would rededicate their lives to christ and ask for the prayers of the congregation that they might serve God better.

${ }^{1}$ Ellen $G$. White, Testimonies for the Church, 9 vols. (Mountain View, CA: Pacific Press Publishing Association, 1948), 2:24. 


\section{CHAPTER SIX}

\section{SUMMARY OF THE PROJECT, RECOMMENDATIONS, AND PERSONAL VALUE OF THE PROJECT}

\section{Summary of the Project}

Needs--The Starting Point

Beginning with the unmet needs, especially of inactive members, which were undefined, this study of Sabbath services as they affect interpersonal relationships more clearly defined the need for inclusion, control, openness, significance, competence, and love.

Believing (a) that God Himself fills humanrelationship needs, often through friends or strangers, and (b) that worship of God could be therapeutic to people who have these needs, I endeavored to determine whether the relationship scores on the Schutz Measures would improve if selected changes in the worship service were instituted.

\section{Worship Was Therapeutic}

The results of the Schutz Measures presented in chapter 4 revealed that the project worship services were therapeutic. Significant improvements were made in 
inclusion, freedom, significance, competence, love, and in the intensity of the desire for openness.

\section{Other Benefits Realized}

One of the greatest benefits of the project was the gain not in the scores but in the awareness of interpersonal needs, feelings, and possible improvements. Two examples of greater understanding were: (1) the realization that active members wanted to become more competent andd (2) that inactive members waned to be seen as more significant.

While small churches frequently think they can not or need not minister to felt needs, the results of the Schutz Measures helped the project church realize that there were not only personal needs but also people to minister to those needs right within their congregation as well as in the community.

Though God created men free moral agents, 1 the control-element scores from the schutz instrument revealed that active members did not feel as free to work as God directs them as they would like. This was due partly to church leaders placing restrictions upon them, partly to members not knowing what is expected of them, and partly to members not knowing how to work. If more

${ }^{1}$ Ellen $G$. White, The Sanctified Life (Washington: Review and Herald Publishing Association, $1937)$, p. 76 . 
ministry possibilities were made clear to members, they would more likely select the ministries that use their abilities, thus realizing increased freedom.

\section{Another Look at Attendance}

Even though, due to inclement weather, I did not expect the average Sabbath attendance to be greater during the project than during the preceding nine months, there were possibly other significant reasons for the lack of increased church attendance.

\section{Crises Stimulate Attendance}

A 1976 California church-growth study reported that "before becoming Seventh-day Adventists, $62 \%$ of the adult baptisms experienced disruptive events in their lives." The five most frequent crises in descending order of frequency were: (1) moving, (2) personal or family emotional crisis, (3) divorce or marital problems, (4) severe financial difficulties, and (5) personal injury or illness. 1

Similarly, studies reported by Gottfried Oosterwal

. affirm what other church growth studies had
already discovered earlier: that people moving from
one area to another are in general much more
receptive to the Eternal Gospel and more open to
accept new church membership than settled
populations. . .

${ }^{1}$ David Abbey, "Church Growth Study for S. E. California Conference of S.D.A.," n.p. 1976, pp. 87, 47. 
Interestingly, the same high receptivity to the SDA message is shown also by people who had changed jobs or positions, or who otherwise were strongly affected by changes in their lives. In all these instances, people stand in need of a new communion where they find stability, meaning in life and fellowship.

Whereas it appears that crisis situations in

people's lives stimulate their church attendance, I assume one reason for their attendance is to obtain help and support.

Ministry to Needs Stimulates Church Attendance

Chaney and Lewis state that

- . church growth occurs best in a church where the needs of the people precede the establishment of organizational patterns. Whether or not the needs of the people are being met should become the criterion by which the organization is judged. . . .

New units grow faster when they. a .are more adaptable to 'need oriented' functioning.'

In their book on evangelism, Engel and Norton state that unregenerate man filters unwanted materials out of his mind. Therefore,

- man's need patterns become a central motiva-
tor. Some of these are physical, others are psychological. Always there is the centrality of

${ }^{1}$ Gottfried Oosterwal, Patterns of SDA Church Growth in North America (Berrien Springs, MI: Andrews University Press, 1976) pp. 25, 26.

${ }^{2}$ Charles L. Chaney and Ron S. Lewis, Design for Church Growth (Nashville, TN: Broadman Press, 1977), pp. 31-33. 
self-seeking. The filter functions to admit those stimuli that are refevant to the self and screens out those that are not.

Inasmuch as church attendance increases when the central motivator of unchurched people--their need for help--is the object of ministry, I conclude that one reason non-church people initially visit a church is that the church provides help for specific problems.

Conclusion Concerning Lower Church Attendance

Since ministry to felt needs during the sermons and discussions was the focus of this project and in light of the results seen in the schutz Measures, I would have expected church attendance to increase. However, attendance decreased. Since I did not introduce the advertising variable, I conclude that one reason attendance did not increase was the lack of communication with the unchurched.

A second reason for a lack of increased attendance may stem from the fact that church members frequently feel they have not been spiritually fed unless they have heard a gospel-doctrinal sermon. Because the material presented was life-situational, some active members may have felt there was insufficient doctrine being presented from the Word, so they attended elsewhere.

\section{${ }^{1}$ James F. Engel, Wilbert Norton, What's Gone} Wrong with the Harvest (Grand Rapids: Zondervan, 1981), p 36 . 


\section{Recommendations Arising from the Project}

Instruction for Beginners Versus

Advanced Instruction for Members

While presentation to the unchurched of Christ as the solution of human need and advanced instruction of church members are necessary, it may not be possible to accomplish the maximum of both in one service because of interest changes that occur at conversion.

Because unchurched people are more interested in receiving help for felt needs than for doctrines that are perceived as having only minimal relevance to life, Engel and Norton point out that to reach the unchurched the pastor must

. bring the word of God to bear in its full-
ness at the points of need. . . The agent of
change starts where people are now and moves them
toward a desired end point within the context of
their existing needs, values, and life-styles.

To obtain decisions for God by unchurched people, the authors continue, it is necessary for the church, the body of christ, to focus

- . on the reasons why a person is at the state of problem recognition and to present the biblical solution in a logical manner, in terms appropriate for that individual's felt needs. Thus, the evangelist clearly presents Jesus as the solution to his or her problem and provides concrete steps to bring the inquirer to the point of saving faith. . .

In short, God expects His body to communicate-to understand the aydience, to speak to felt needs, to build awareness.

${ }^{1}$ Ibid., p. 28 .

${ }^{2}$ Ibid., pp. 51, 52 . 
Later in their book Engel and Norton again state the necessity of speaking about felt needs and give examples of these needs. They say

\begin{abstract}
- . the gospel, of course, is not relevant if it is communicated as an abstraction. This requires that the message utilized in the various media speak directly to the needs of people in areas such as marriage, occupation, and materialism. . . In this context, then, it is necessary also to focus on showing that man is a sinner and that ${ }_{1}$ Jesus provides the key to satisfaction of felt need. 1

Keith Miller, writing about the Christian life, expresses the need for practical, "market place" religion. He says:
\end{abstract} - . modern disciples are not satisfied with abstract statements of doctrine--however accurate. They feel a strange dichotomy between the church's doctrinal statements and the problems of the market place as they actually are.
Out of the resulting frustration has come a feeling that the church is too 'philosophical' in its orientation and that the philosophic mind easily forgets its base in the actualities of a man's life.

Unchurched people tune out that which is not practical. Therefore the objective of evangelistic preaching should be to present christ-centered helps for the problems of everyday life. Looking at Christ as our example, Miller notices that Christ, in his preaching as well as in his living, made religion a matter of action and not just a system of beliefs. Miller continues,

${ }^{1}$ Engel and Norton, p. 92.

${ }^{2}$ Keith Miller, The Taste of New Wine (Waco, TX: Word Books, 1965), p. 16 . 
Christ's criteria for a godly life were not doctrinal as ours so often are. His had to do with allegiance to Himself and the fruits that allegiance produced in a man's relationship with other men. - . A life of prayer is to be judged ultimately not so much by even our devotion in praying and witnessing and inner moral rectitude as by whether or not we have fed the hungry, clothed the naked and loved the loveless stranger.

Every evangelistic worship service can inspire practical godliness, and each can help listeners to cross the barriers that separate the church member from the unchurched to bring practical help. Miller says,

Christian prayer, inevitably drives a man. . . beyond the circle of his little group of Christian friends and across the barriers between social, racial and economic strata to find the wholeness, the real closeness of christ in that involvement with the lives of His lost and groping children whoever and wherever they may be.

Because unchurched people absent themselves from church for a lack of hearing life-situational sermons and seeing practical results in the lives of Christians, ministers should present ways to live one's beliefs. Thus Ellen G. White points out the need for practicing one's beliefs and for preaching practical sermons. She says that

- . every important truth received into the heart must find expression in the life. It is in proportion to the reception of the love of Christ that men desire to proclaim its power to others.

${ }^{1}$ Ibid., p. 64.

2 Ibid.

${ }^{3}$ E. G. White, Review and Herald, February 19 , 1889 , p. 282 . 
The example of Christ in linking Himself with the interests of humanity should be followed by all who preach His word, and by all who have received the gospel of His grace. We are not to renounce social communion. We should not seclude ourselves from others. In order to ${ }_{1}$ reach all classes, we must meet them where they are.

Since the work of the church is to prepare people to minister to the needs of humanity ${ }^{2}$, could not lifestyle preaching provide some training during the Sabbath services when the largest number of members are present?

Every church should be a training school for Christian workers. Its members should be taught how to give Bible readings, how to conduct and teach Sabbath School classes, how best to help the poor and to carre for the sick, how to work for the unconverted.

Some might argue that the previous quotation refers to training that should be done outside of the church service, but I think that restriction is not necessary. The following quotation refers directly to preaching during the worship hour and expresses the need for training.

The people have listened to too much sermonizing: but have they been instructed as to how to labor for those for whom Christ died? Has there been a line of work devised and laid out before the people in such a way that each one saw the necessity of taking part in the work?

\section{${ }^{1}$ E. G. White, Desire of Ages, p. 152 . \\ ${ }^{2}$ E. G. White, The Acts of the Apostles} (Mountain View, CA: Pacific Press Publishing Association, 1911), p. 9 .

${ }^{3} E$. G. White, Ministry of Healing (Mountain View, CA: Pacific Press Publishing Association, 1942), p 149 . 
It is evident that all the sermons that have been preached have not brought up this kind of labor, and the churches are withering up because they have failed to use their talents in diffusing the light of truth to others. Careful instruction should be given that will be as lessons from the master that all may put their light to practical use in benefiting others.

Because life-situational sermons appeal to the unchurched community and because instruction in practical Christianity is needed, those who present the sermons in the project church need to speak about such practical subjects as materialism, marital relations, and child training if it is going to evangelize the community during its church services. In contrast, if the services are structured to indoctrinate with little reference to life situations, all other factors being unchanged, the members may know the doctrines better, but church growth may become stagnant.

\section{Participation Versus Observation}

The project church also needs to structure the services so as to actively involve church members in the services rather than to have the members simply observe a few leaders. To increase members' participation in the service during the project, the time for the pastoral prayer was lengthened so as to include receiving prayer

${ }^{1}$. G. White, "An Appeal to Our Churces on Behalf of Missionary Work," Home Missionary Leaflet No. 9, cited by Oosterwal, p. 101. (Italics supplied.) 
requests from the congregation. Engel and Norton commend this type of activity and then, seeking to stimulate more involvement, they ask,

Does anyone ever stand up and say, 'I'd like to praise God today because of what He taught me in - . '? Or 'I need your prayers, because for some reason I just feel depressed. It has hung on for days, and I can't figure it out.' No, such personal things seem to have no place in our churches today. No wonder our services have a tendency to become tasteless and ineffective!

Webber, speaking expectantly about participatory worship services, explains:

We may well be part of an exciting change--a change from passive worship to active worship - . . In other words, wORSHIP IS A VERB. It is not something done to us or for us, but by us.

In many churches. . .the pastoral prayer substitutes for personal prayer. It puts all prayers and requests into the mouth of the pastor. But in those churches where prayer has been returned to the people, each individual is able to pray, to make his supplication and his thanksgiving know to God.

During the project, members participated in the main morning prayer. Even though one member said that laymen offering the prayer made the prayer too common, the leaders of the church need to recognize the spiritual competence of the laity and include them in the act of worship if the church is to remain a strong growing organization.

${ }^{1}$ Engel and Norton, p. 117

${ }^{2}$ Robert Webber, Worship Is a Verb (Waco, TX: Word Books Publisher, 1985), pp. 12, 20. 
Members also became actively involved during the post-sermon discussions and dedication times. Concerning participation during discussion, Engel and Norton point out:

Learning is an interaction between student and teacher, with primacy placed on individual expression. . . .

Students of all ages tend to chafe in a lecture situation where their individuality either is quashed or not given opportunity for expression.

Elien White speaks of the need for members to testify to what God has done in their lives, if the unchurched are to be saved.

As witnesses for christ, we are to tell what we know, what we ourselves have seen and heard and felt. If we have been following Jesus step by step, we shall have something right to the point to tell concerning the way in which he has led us. We can tell how we have tested $H$ is promise, and found the promise true. We can bear witness to what we have known of the grace of christ. This is the witness for which the Lord calls, and for want of which the world is perishing.

Our confession of His faithfulness is Heaven's chosen agency for revealing Christ to the world. We are to acknowledge $H i s$ grace as made known through the holy men of old; but that which will be most effectual is the testimony of our own experience. We are witnesses for God as we reveal in ourselves the working of a power that is divine. Every individual has a life distinct from all others, and an experience differing essentially from theirs. God desires that our praise shall ascend to Him, marked by our own individuality. These precious acknowledgments to the praise of the glory of His grace, when supported by a Christ-like life, have an

${ }^{1}$ Engel and Norton, p. 128. 
irresistible power, that works for the salvation of souls.

Commenting on the need of each member being actively involved in worship, Webber says:

Worship connects me with the past, gives meaning to the present, and inspires hope for the future as my soul and spirit become blended again into the drama of Christ's life, death, and resurrection.

But for so many people today, worship has become dull, intellectual, cold, formal and alienating - . . which ultimately has little affect on what goes 2 on in a person's life during the rest of the week. ${ }^{2}$

If the project church will structure its services so as to give members a more active role in worship, there will be more appeal not only to members but also to the unchurched. As Engel and Norton say, this must not be ignored.

We wonder what might happen in the church if the true meaning of worship were to penetrate the sunday morning service? Perhaps joy would be contagious and a sense of the miraculous would once again pervade God's people. A dream? Perhaps. Whatever the case, worship is communication from God's people to 3 Him, and its rightful function must not be ignored.

\section{Add a Second Service}

Whereas a church needs to meet the felt needs of the unchurched community and at the same time inspire sanctification in its membership. I would recommend that

${ }^{1}$ E. G. White, Desire of the Ages, pp. 340,347 .

${ }^{2}$ Webber, pp 28, 29. (Italics supplied.)

${ }^{3}$ Engel and Norton, p. 139. 
the project church add a second service to its weekly program and decide which of the two following revisions of its Sabbath services be used for the regular 9:30 a.m. worship time.

1. Make the 9:30 a.m. worship service format informal and needs-oriented las the first seven weeks of the project were) and add an alternate Friday night or Sabbath afternoon formal nurturing service for the benefit of members, or

2. Keep the Sabbath worship service formal as was done during the final three weeks of the project, but have an informal and needs-oriented service at the alternate service time.

\section{Listen, Acknowledge,} and Touch

Having observed the project church for more than a year, I conclude that it may have been too little concerned with ministering to personal needs. The members need to listen to, acknowledge, and emotionally touch one another and visitors--as was done during the prayer-request time, the church-life interviews, the after-sermon discussion, and the Sabbath school instruction time. They need to touch one another physically--as in the placing of their arms around one another during the morning prayer and during the morning greeting--to communicate love, interest, and acceptance. 
The church members need to be honest with one another--acknowledging their needs, desires, strengths, and weaknesses, and openly receiving and offering help. The younger members of the church could lead in honest openness, letting the older ones observe without participating until they are comfortable.

Some may question the need of touch to communicate love. Is it necessary or even beneficial within the church?

Jerry Lee, chairman of the department of Psychology at Loma Linda University, reporting on a study of membership loss of California Seventh-day Adventists, states:

One of the clearest findings in the study is the importance of social forces in determining who leaves the church. A lack of Adventist friends, and a lack of visits from church members and pastors were both found to be related to leaving the church. In addition, when both members and apostates rated various influences toward leaving the church. . . perceived member coldness. . .ranked. . fourth. . . in a list of 20 possible influences.

The authors of the 1977 church growth study make the comment that it appeared that individuals were loved into the church. Our results with regard to influences on entering the church tends to confirm this idea. . . What this study of former members shows is that a lack of love drives people out of
the church.

While this study did not investigate the effect of physical touch conveying love within the church

${ }^{1}$ Jerry Lee, "A Summary of a study Concerning Church Membership Loss of The Southeastern California Conference of Seventh-day Adventists," (N.p., 1980), p. 7 . 
service, the study showed the need to love to win and hold people in the church.

In the book A Time for Caring, Bach and Torbet comment on caring for people of any age:

Caring activists understand that gestures of affection, though nonverbal, are powerful communicators. They understand the comforting effects of a touch, the heafing power of a kiss, the appropriate use of the hug.

It is now well-known that babies who receive stimulation by touch score higher on mental tests, gain weight faster, roll over, crawl, walk sooner, and smile sooner and more frequentiy. ${ }^{2}$ But Bach and Torbet bring out some of the problems that one encounters when trying to love older children and adults.

Simple physical contact is another part of active care. But whether to touch, and how, and when have become loaded questions. In this age of sexual liberation, people paradoxically are starved for physical affection and afraid to ask for it.

Because people are starved for affection, the church of all places needs to be the safest place on earth to love as Christ commanded. The authors comment further on the problems of expressing love through touch.

${ }^{1}$ George Bach and Laura Torbet, A Time for Caring (New York: Delacorte Press, 1982), p. 100 .

${ }^{2}$ Ann Myers and Carla Johnson, "Infant Stimulation, New Concepts in Neonatal/Infant Growth and Development" Continuing Education Nursing Notes, (Garden City, KS:

St. Catherine's Hospital, 1983)

${ }^{3}$ Bach and Torbet, p. 99. 
Parents are afraid of smothering their children with love. Sexual acts lacking in affection are commonplace. Reaching out to touch others can be misconstrued these days as asking for too much, as being a come-on, as spoiling the child, as a demand for unwanted intimacy, as sexual license, as phony feeling. Too, some gestures of affection have become so highly ritualized that they lose their meaning. Ladies meeting for lunch kiss the air in the vicinity of their friend so as not to smear their lipstick. Distanced husbands and wives exchange good-bye-inthe-morning, hello-in-the-evening kisses devoid of feeling. For some, the social kiss is the equivalent to the handshake, magnanimously bestowed on every passing cheek.

In spite of the problems of using physical contact to convey love, I believe church members need to learn and practice appropriate ways to convey love through touch. Again Bach and Torbet comment:

People who are comfortable with their caring actions are not afraid of being misunderstood, not afraid of physical contact with those they care for, not afraid of showing affection, for they are appropriate to the kind of attention they show.

It must be recognized that not everyone is a touchable person. Some are repulsed by closeness. Bach and Torbet recognize this and give an illustration of such a person.

When Grace first met Bill, he was very wary of physical overtures; at the same time he felt very alone. She, on the other hand, was very affectionate and outgoing, given to hugs and backrubs. But she was also both sensitive to the fear of affection behind Bill's glib, self-possessed manner and sympathetic to it. She knew that affection was what he ${ }_{1}$ craved, even as she knew he would withdraw from it. 1

${ }^{1}$ Bach and Torbet, pp. 99, 100. 
The illustration continues by giving advice about

how to love without offending the untouchable person.

I feel good about how I helped Bill overcome his fear of affection. In the past I've had the tendency to overwhelm or embarrass people. Now I've learned that the bulldozer approach doesn't work. What I did was ask Bill to give me affection. I let him be the initiator and set the pace. Instead of smothering him with solicitation and kisses, I would tell him how frazzled I felt from my day and how much I looked forward to a big hug. Pretty soon he was offering the support and affection. And recently he's felt confident enough to say, "Tonight I need the hug." Bill feels much more confident with my demonstrativeness, and I feel I've learned something about how to love someone. . . . concerned.

Caring ${ }_{1}$ action contributes to the growth of all

Love, conveyed by touch, is important within the church. Given appropriately, it wins visitors and holds members loyal to the church.

\section{Positiveness and Affirmation}

Because most people attempt a feat only if they are confident of success, it is important to conversionsanctification to speak optimistically. To inspire confidence, I recommend that pastors preach, "You can" and "He has" rather than "You should."

Since members like to be recognized and affirmed but are embarrassed when it is done publicly, the church could announce biweekly the name of a member who is to be recognized and encourage people to tell the selected

\footnotetext{
${ }^{1}$ Bach and Torbet, p. 100
} 
member, one-on-one, why they appreciate him or her. Inspired with confidence and feelings of significance, members are more likely to try and to feel better about doing new things.

\section{Watch and Respond}

As church members become more open, church leaders need to watch for previously dormant interests and unexpressed needs of active--and especially of inactive--members. The Holy spirit will reveal needs within a congregation or community and provide the lay-ministry to meet those needs. ${ }^{1}$ Ten weeks was not long enough to see members become involved in new ministries, but I anticipate that because people want to improve their talents of service--if church leaders will reveal ministry resources--members will, in response to the Holy Spirit, select ministries for the benefit of the church and thereby realize greater freedom and satisfaction. Members want to know what is possible and what is expected of them, and they want freedom to do what the Holy Spirit directs them to do.

\section{Assistance Versus Leadership}

In contrast to the incompetence people may feel when things are done for them, participation increases

\section{${ }^{1}$ Frank Tillapaugh, The Church Unleashed}

(Ventura, CA: Regal Books, 1982), pp. 51, 52 . 
feelings of competence, though those feelings increase slowly. Church members want to participate in something they consider significant, but they do not necessarily want to lead. Often they want to be with and to assist a leader, rather than to do things alone for him. The resulting fellowship not only improves the feeling but also the fact of competence. Therefore church leaders need to include non-leaders in their church activities, i.e., take non-leaders with them when they visit in the hospital or give a Bible study.

\section{Stress and Sharing}

Experiences

The Schutz Measure indicated that during the project members retreated to increased privacy. This is acceptable, and while there is a need for honesty and openness, church leaders need to monitor the worshipers lest fear and insecurity increase. Leaders can alter sharing times when there is tension, e.g., when a leader learns before church that a member has had a hard week at work or that another is insecure about possible loss of work, that leader can accept the silence of the members during sharing times.

\section{Altar Calls}

Most SDA churches do not have altar calls each Sabbath, but during the closing part of each project worship service, participants were invited--and every 
Sabbath one or two members chose--to rededicate some aspect of their lives to God. It would be easy in these circumstances for nonmembers to make public declarations of a decisions for Christ or His church also. I recommend that this continue.

\section{Annual Evaluations}

Traditionally SDA ministers evaluate themselves on the basis of baptisms, Ingathering, achieving several subscription goals, and a few other minor things. I would suggest that pastors should, every year, give their church members the Schutz Measures and compare the scores with those of the preceding years. This yearly comparison would help the pastor (1) monitor the spiritual growth of the church members, (2) discern the progress of the congregation as a whole, and (3) evaluate the results of his ministry to the congregation. If a member, or the total membership, regresses to greater feelings of incompetence, the pastor along with his advisors could then evaluate the member(s)' involvement in church activities.

\section{More Verification Needed}

I would recommend that other pastors make use of the Schutz Measures to determine whether the effects of worship services seen in this project could be generalized. 


\section{Personal Value of the Project}

The results I have realized personally from the nearly two years I have been involved in preparing for and carrying out this project, are as follow:

1. A greater understanding of, and appreciation for, the following needs and desires of the church members: (a) the need for formality in worship which contributes to awareness of and reverence before the infinite God; (b) the desire to be wanted and needed, to feel significant; and (c) the need for both familiarity and privacy.

2. A greater understanding of the abilities and competence of the church members and of their desires to be co-workers with church leaders. Having listened to the comments of members during the post-sermon discussions I have also gained a greater appreciation for the ability of laymen to suggest secular applications of religious principles.

3. A greater confidence in and satisfaction with my ability to lead a congregation (a) to demonstrate more love and acceptance, (b) to be open with each other and to discern the personal margins between openness and privacy, (c) to help people feel significant because of their personal interests and abilities, and (d) to help people feel free to be themselves and allow others the same freedom. This 
confidence has resulted from seeing improvement in the results from the Schutz instrument. And while over the years I have developed a philosophy of ministry in a measure revealed in this report, the documentation of the ideas presented has also increased my confidence in my ministry.

4. A joy in seeing more people dedicate their lives to God as each service came to a close.

5. An eager anticipation to see the results of continuing the project worship format over a longer period of time. 
APPENDIX A

Felt Needs Survey Materials 


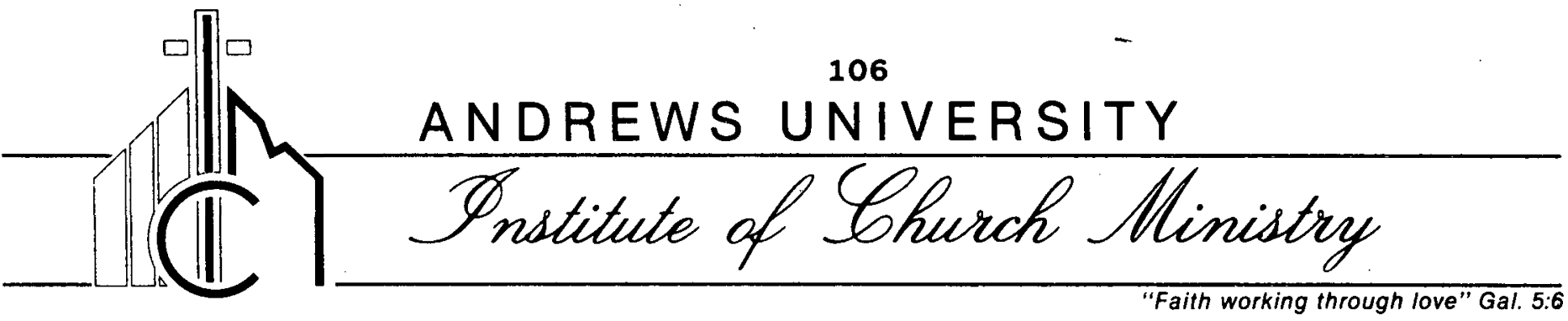

Roger L. Dudley, Ed.D. Director

Sara M. K. Terian, Ph.D. Assistant Director

June 7,1986

Dear Friend,

All of us have concerns and even worries that are not being adequately helped. To study these needs, Andrews University has selected you to participate in a telephone survey.

We would appreciate your sharing your feeling by marking the enclosed survey. You do not need to return anything! After filling out the survey just place the completed form next to your phone. This Saturday, oct. 18, between $1: 00$ and 4:00 we will be phoning to receive your response.

CONFIDENCE? Your name is used because we need it for phoning purposes but the information you share will not be revealed in any way connected with your name.

Again we repeat, YouR response is important. So please take three minutes right now and mark your survey form and place it by your phone.

sincerely yours,

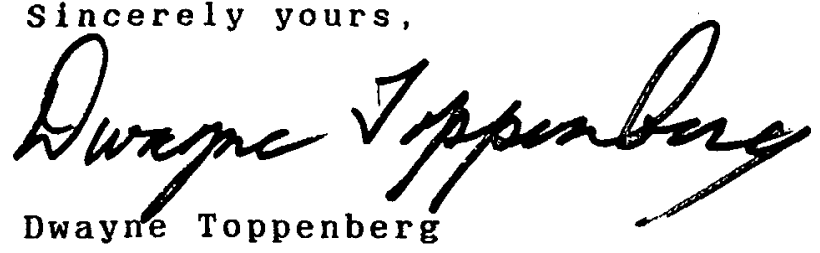

Survey coordinator 


\section{Feeds Surver Conducted by Andrews University}

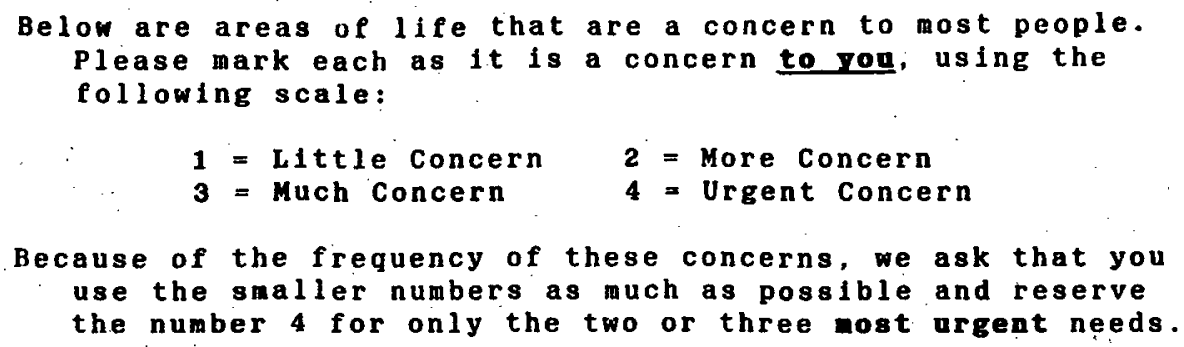

( ) 3. Self-worth: depression, growing older, feeling satisfaction with ones importance and abilities, seeing purpose in ones life

(_) 4. Friendships: loneliness, fear of meeting people, having the right balance between privacy and revelation of self, being included in activities, freedon to be one's self

( ) 5. Time Pressure \& stress: feeling pressure, too many things to do, wanting more recognition

(__) 6. Health: substance abuse (cigarettes, alcohol, coffee) getting exercise, having good nutrition, and adequate rest, diminishing strength

(_-_) 7. Safety: fear of urder, rape, theft, fire, war

(__- 8. The Future: aging, facing death, peace with God, salvation, heaven, hell

(__) 9. Education: quality of teachers, subjects taught, the learning success of students

(__) 10. Entertainment Recreation: movies, TV, music, vacations, sports

(__) 11. Child Training: discipline, loving children, neatness, freedon versus control of adolescents

(_-) 12. Marriage: loneliness, pleasant companionship, acceptance, communication: both pleasant and stressed

(_-_ 13. Life: seeing purpose in living. finding happiness in a world of discord, why God permits suffering and inconsistencies

) 14. Which concern above is most important to you? 
13. Do you have a concern we've not included?

16. List two things about the concern of 14 above that are a problen to you.

1.

2 .

17. How could you be helped with thia concern?

18. What is your feeling about the help for this concern that churches in general are giving?

(_-_) 19. What would you most likely do if a church offered practical help with this concern?

(1) Ignore the help

(2) recelve the help if offered by ay own church

(3) recelve the help it offered by any church but with fear of the church's intention

(4) recelve the help without fear

20. What is your race:

(3) Caucasian

(1) Asian

(4) HIapanic

(2) Black

21. What age bracket are you in: (1) under 25
(2) 26-35
(3) $38-48$
(4) 46-55
(5) $56-65$
(8) $65+$

(__) 22. Select the numbera that apply to you (1) enployed (2) unemployed (3) handlcapped (4) retired (5) student

(_-) 23. Select your higheat level of education conpleted.
(1) elenentary
(4) $\operatorname{col11ege}$
(2) high school
(3) Junior college
(6) doctorate

(_f) 24. Merital statue: (1) never married (2) presently married (3) divorced (4) separated (5) widowed

25. What church do you nost often attend?

(_) 26. What is the sex of the respondent? $A$ B 
Needs Survey Conducted by Andrews University

Tabulation of Responses

Questions 1 to 13

Question Little More Much Urgent No Number Concern Concern Concern Concern Response

$\begin{array}{rrrrrr}1 & 6 & 8 & 11 & 7 & 0 \\ 2 & 15 & 1 & 9 & 7 & 0 \\ 3 & 10 & 7 & 5 & 10 & 0 \\ 4 & 14 & 4 & 4 & 10 & 0 \\ 5 & 9 & 8 & 9 & 6 & 0 \\ 6 & 9 & 9 & 7 & 7 & 0 \\ 7 & 11 & 6 & 6 & 9 & 0 \\ 8 & 12 & 4 & 8 & 8 & 0 \\ 9 & 6 & 12 & 5 & 9 & 0 \\ 10 & 16 & 7 & 6 & 3 & 0 \\ 11 & 8 & 1 & 11 & 11 & 1 \\ 12 & 9 & 6 & 8 & 9 & 0 \\ 13 & 11 & 4 & 7 & 10 & 0\end{array}$

Question 14 "Which concern above is most important to you?" Question

$\begin{array}{llllllllllllll}\text { Numbers } & 1 & 2 & 3 & 4 & 5 & 6 & 7 & 8 & 9 & 10 & 11 & 12 & 13\end{array}$

Number of

$\begin{array}{llllllllllllll}\text { Responses } & 5 & 1 & 4 & 3 & 3 & 4 & 0 & 2 & 3 & 0 & 3 & 1 & 2\end{array}$

Question 19 "What would you most likely do if a church offered practical help with this concern?"

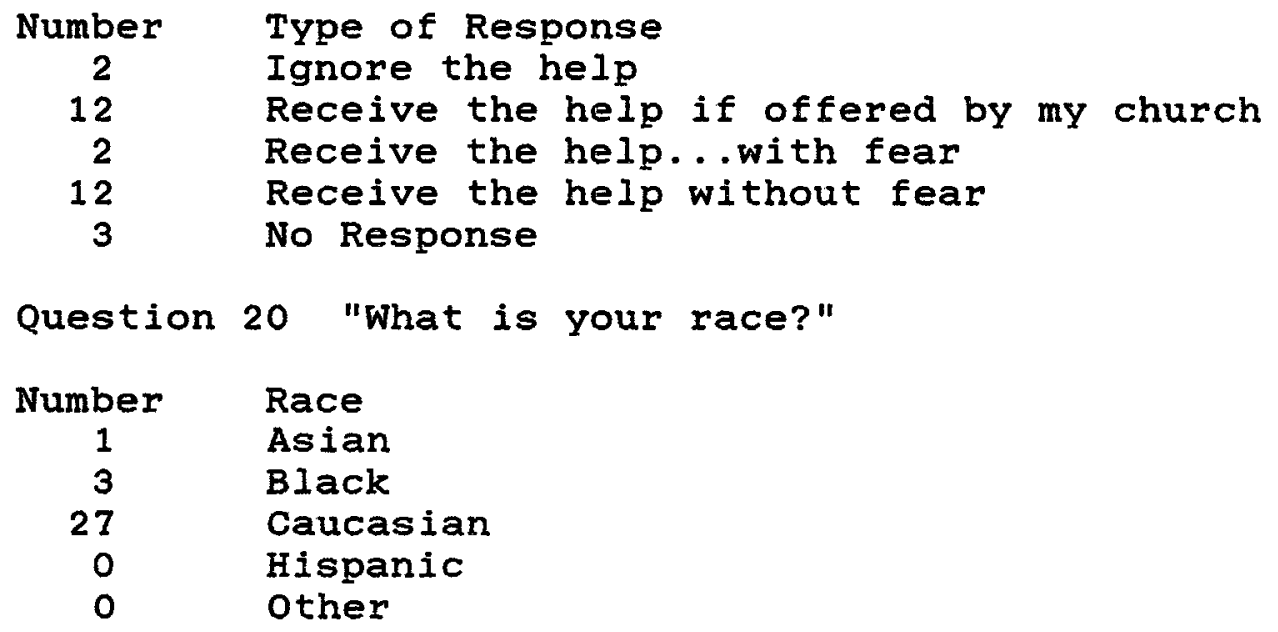




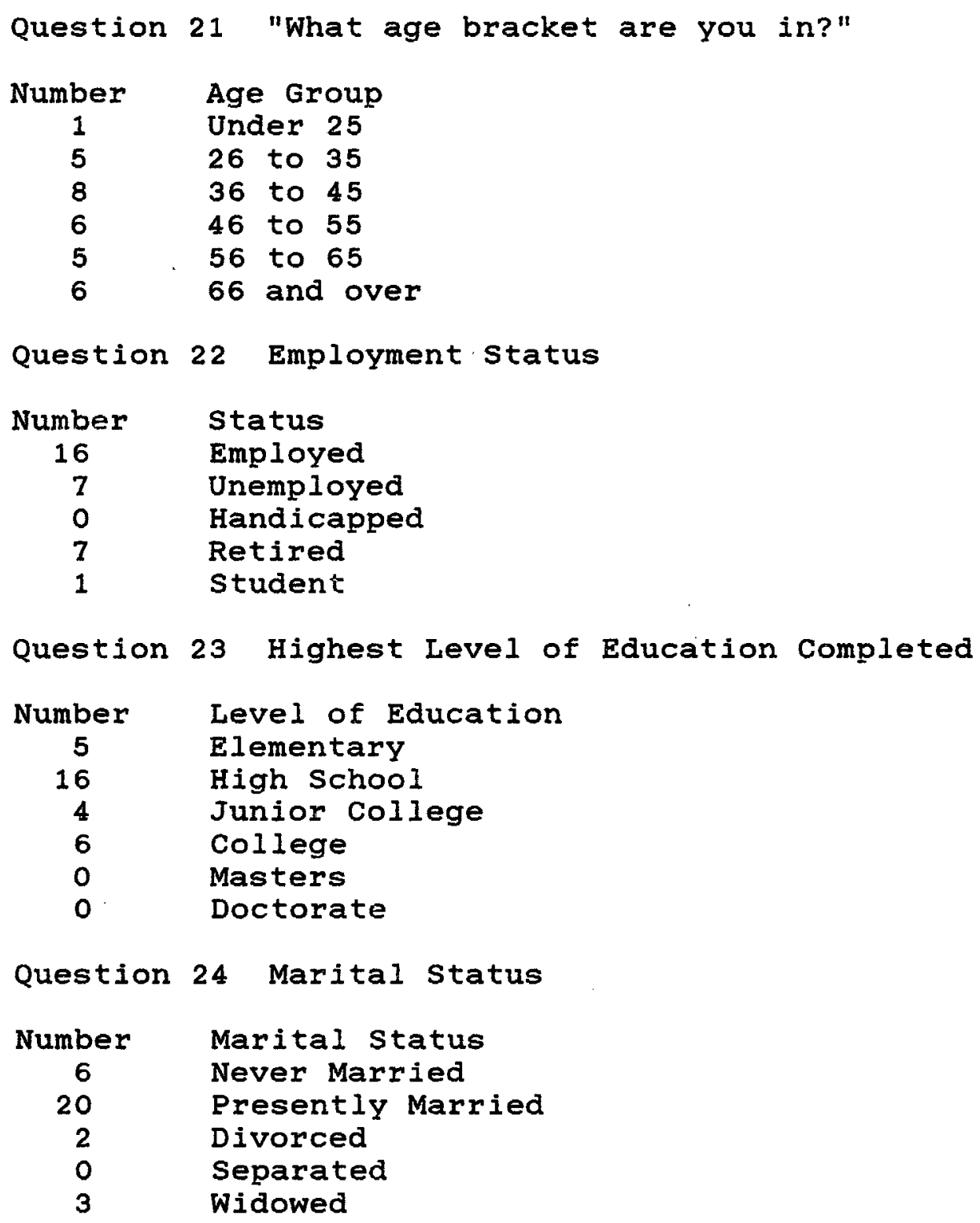


APPENDIX B

Project Evaluation Questionnaires 
Post Project Questionnaire

Directions: Circle the number that best describes your opinions on the 1 to 4 scale, or circle the No Opinion.

1. Did you like this Sabbath service?

No $1 \quad \begin{array}{llllll} & 2 & 3 & 4 & \text { Yes or No Opinion }\end{array}$

2. Did you like the order of the service?

No $1 \quad 2 \quad 2 \quad 3 \quad 4$ Yes or No Opinion

3. Do you dislike or like the new music style?

$$
\text { Dislike } \quad 1 \quad 2 \quad 3 \quad 4 \quad \text { Like it or No Opinion }
$$

4. Do you dislike or like our new prayer request time?

$$
\begin{array}{llllll}
\text { Dislike } & 1 & 2 & 3 & 4 & \text { Like it or No Opinion }
\end{array}
$$

5. Do you dislike or like the after-sermon discussions of applications?

$$
\text { Dislike } \quad 1 \quad 2 \quad 3 \quad 4 \quad \text { Like it or No Opinion }
$$

6. Would you like to sit in a circle during Sabbath School discussion times, rather than sitting in rows?

$$
\text { No } \quad \begin{array}{llllll}
1 & 2 & 3 & 4 & \text { Yes or No Opinion }
\end{array}
$$


Post Project Questionnaire

Directions: Circle the number that best describes your opinions on the 1 to 4 scale, or circle the No Opinion.

1. Did you like this Sabbath service?

No $1120 \quad 3 \quad 4 \quad$ Yes or No Opinion

2. Did you like the order of the service?

No $11 \quad 2 \quad 3 \quad 4 \quad$ Yes or No Opinion

3. Do you dislike or like the new music style?

Dislike $11 \quad 2 \quad 3 \quad 4 \quad$ Like it or No Opinion

4. Do you dislike or like our new prayer request time?

Dislike $11 \quad 2 \quad 3 \quad 4$ Like it or No Opinion

5. Do you dislike or like the after-sermon discussions of applications?

$$
\text { Dislike } \quad 1 \quad 2 \quad 3 \quad 3 \quad 4 \text { Like it or No Opinion }
$$

6. Would you like to sit in a circle during Sabbath school discussion times, rather than sitting in rows?

$$
\text { No } \quad 1 \quad 2 \quad 3 \quad 4 \text { Yes or No Opinion }
$$

7. If you had the music tape, would you like to listen to it at home during the week?

$$
\text { No } \quad 1 \quad 2 \quad 3 \quad 4 \quad \text { Yes or No Opinion }
$$

8. Do you like or dislike the topics that have been presented these past five weeks?

$$
\text { Dislike } 1 \quad 2 \quad 3 \quad 4 \quad \text { Like or No Opinion }
$$

9. Do you feel the services are to secular, not presenting God and his grace and power enough?

$$
\text { No } \quad \begin{array}{llllll}
1 & 2 & 3 & 4 & \text { Yes or No Opinion }
\end{array}
$$


Directions: circle the number or word that best describes your opintons.

1. Did the Sabbath services deal with people's needs?

$\begin{array}{llllllll}\text { No } & 1 & 2 & 3 & 4 & \text { Yes or No Opinion }\end{array}$

2. Did you prefer the formal or informal worship services? Formal Informal No opinion

3. Did you dislike or like the contemporary music style?

Dislike $1.25 \quad 3 \quad 4$ Like or No Opinion

4. If you had the music tape, would you like to listen to it at home during the week?

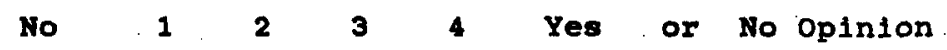

5. Circle the times you wish to use the contemporary music:

For Sabbath School For Church. Discontinue $1 \mathrm{t}$

6. Did you dislike or like our new prayer request time?

Dislike 1 2 $3 \quad 3 \quad 4$ Like it or No Opinion

7. Did you dislike or like the after-sermon discussions of applications?

Dislike 1 2 344 Like 1 t or No Opinion

8. Would you dislike or like to sit in a circle during Sabbath School lesson study rather than sitting in rows?

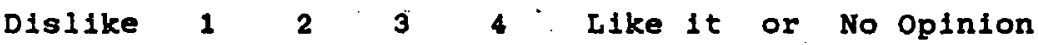
9. Did you dislike or like having instruction before the

Dislike 1 2 $3 \quad 4$ Like it or No Opinton

10. Did you like or dislike the topics that have been presented the past ten weeks?
Dislike
2
$2 \quad 3 \quad 4$
Like or No Opinion

11. Did you feel the services were to secular, not presenting God and his grace and power enough?

$$
\text { No } \begin{array}{lllllll} 
& 1 & 2 & 3 & 4 & \text { Yes or No Opinion }
\end{array}
$$

12. Did you dislike or like the time for rededication and testimony at the end of the worehip service?

Dislike $1 \quad 2 \quad 3 \quad 4$ Like or No Opinion

13. Did you dislike or like the offering being a part of the final dedication part of the service.

$$
\text { Dislike } 1 \quad 2 \quad 2 \quad 3 \quad 4 \text { Like or No Opinion }
$$

14. Did you dislike or like greeting one another and visitors during announcements?

$$
\text { Dislike } 13 \quad 2 \quad 3 \quad 4 \quad \text { Like or No Opinion }
$$

15. Did you dislike or like being encouraged to hug one another during greeting?

Dislike $1 \quad 2 \quad 3 \quad 4$ Like or No opinion

16. How many times a month would you like a sermon like the ones on child-training, nutrition, finances, and etc.?

$$
1 \quad 2 \quad 3 \quad 4
$$

17. How many times a month would you like to have the post-sermon discussions?

$12 \quad 3 \quad 4$




\section{APPENDIX C}

The Schutz Measures Instrument and Results 
The Church to Me Relationships Adaptation from The Schutz Measures: $R$ (You to Me)

You should respond to the following statements in an effort to provide an honest description of the behevior of the church, church members, and church officers, towards you, and your perceptions of their feelings toward you.

You will need to respond to each of the 54 statements in terms of "the way things are." After responding to the 54 statements once, you are asked to go through the 54 again and answer them in terms of "how you would like" or "want" the church, church members, and church officers to behave and feel toward you.

Mark all your responses on the separate response sheet.

Behavior

1. The church members spend time with me.

2. Church members are dominant when they are with me.

3. Church members are, or I want them to be, honest with me.

4. They join my group.

5. They have me do things they want done.

6. They confide in me.

7. They include me in their informal social activities.

8. They influence my actions.

9. They keep from getting to me.

10. They include me in their plans.

11. They take charge of things when I am with them.

12. They keep their private feelings to themselves.

13. They have me around them.

14. They have me do things the way they want them done.

15. They keep same things hidden from me.

16. They join me when I an doing things with other people.

17. They make the decisions when we are together.

18. They keep from me some things about themselves.

19. They are with me.

20. They tell me what to do.

21. They tell me everything that is important about themselves.

22. They include me in the things they do.

23. They let me do whatever I want to do.

24. They beep scme things private from me.

25. They participate in my activities.

26. They order me around.

27. They have a close, open relationship with me.

The Schutz Measures, Copyright 1982 by Will Schutz Associates. Consulting Psychologists Press, 577 College Áve.. Palo Alto, CA 94306.
28. They feel that I an important.

29. They feel that they cannot rely on my judgment.

30. They are warm toward me.

31. They feel I am a significant individual.

32. They are skeptical of my ablitities

33. They feel affectionate toward me.

34. They feel that I do not mean anything to them.

35. They admire my competence.

36. They feel personally close to me.

37. They feel neutral toward me.

38. They feel adniration for my abllities.

39. They feel personally distant from me.

40. They feel unconcerned about me.

41. They feel trust in my abilities.

42. They feel bitter towand me.

43. They feel indifferent toward me.

44. They feel suspicious of my competence.

45. They feel cordial toward me.

46. They feel interested in me.

47. They trust in competence.

48. They feel very friendly towand me.

49. They feel intrigued by me.

50. They feel confidence in my abilities.

51. They feel cool towand me.

52. They feel stimulated by me.

53. They feel that they can depend on $\mathrm{my}$ judgement.

54. They feel hatred for me. 
The Schutz Measures

Response Sheet: $\mathrm{R}$ (You to Me)

My Name

Your Name

Date Age Sex

The numbers in the answer boxes mean the following:
$1 \begin{aligned} & \text { Definitely } \\ & \text { not true }\end{aligned}$
2 Not
3 Tends to be
4 be true $\quad 5^{\text {True }}$
6 Especially

All the statements should be responded to by drawing a diagonal line through the appropriate box. Be careful to match the item number on the test sheet with the corresponding number on this sheet.

The following 27 items should describe how, in your opinion, the other person behaves toward you:

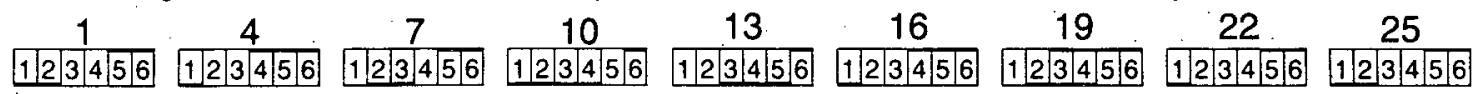
$\begin{array}{lllllllll}2 & 5 & 8 & 11 & 14 & 17 & 20 & 23 & 26\end{array}$

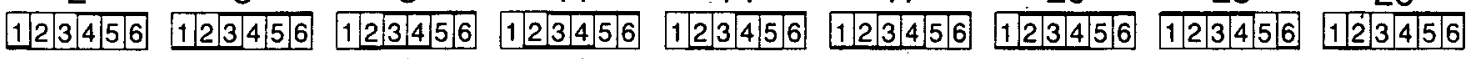

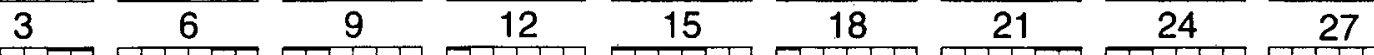

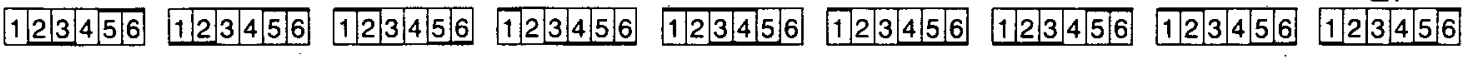
Items 28 through 54 should describe how you think the other person feels toward you: 28 31 34 37 40 43 46 49 52

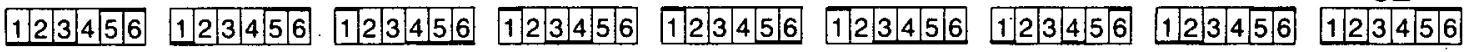

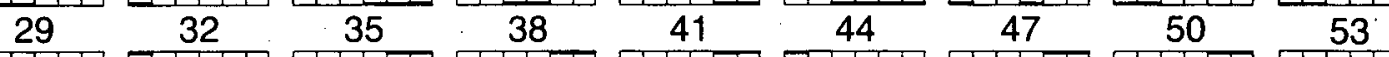

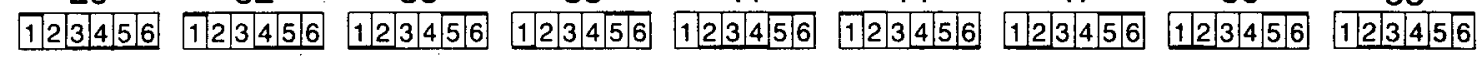

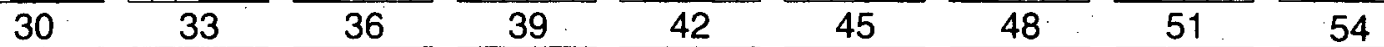

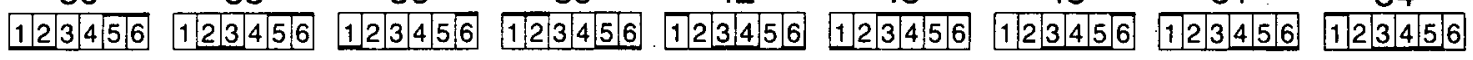
Now return to item 1 on the test and answer the first 27 items in terms of how you want the other person to behave toward you: 1 4
4 $\frac{10}{13}$
13

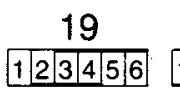
$22 \quad 25$

\begin{tabular}{l|l|l|l|l|}
16 \\
\hline 1 & 2 & 3 & 4 & 5 \\
\hline
\end{tabular}

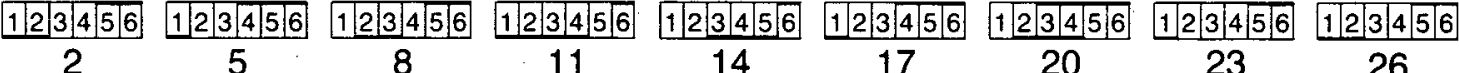

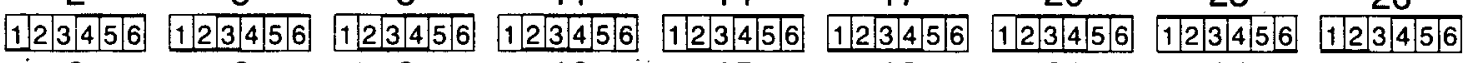

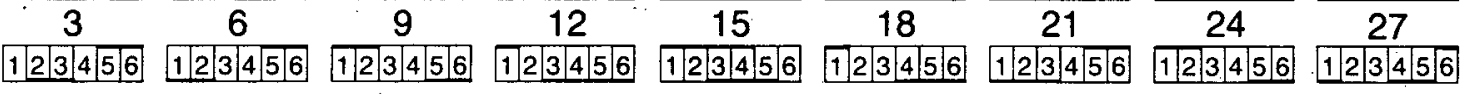

The remaining items should be answered in terms of how you want the other person to feel toward you:
28
31
34
37
$40 \quad 43$
$46 \quad 49$
52

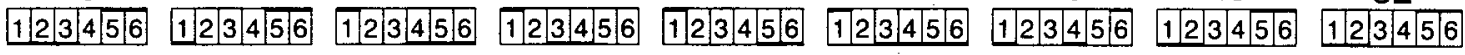
29 32 35 38 41 44 47 50 53

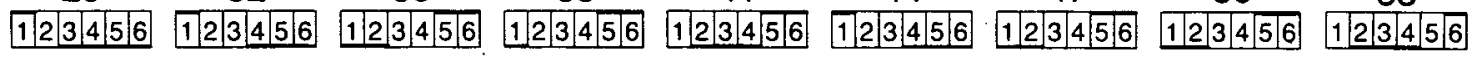
30 33 $36 \quad 39$ $42 \quad 45$ $45 \quad 48$ 51 54

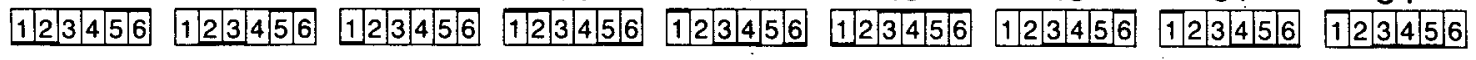
Do not write below this line unless instructed to do so.

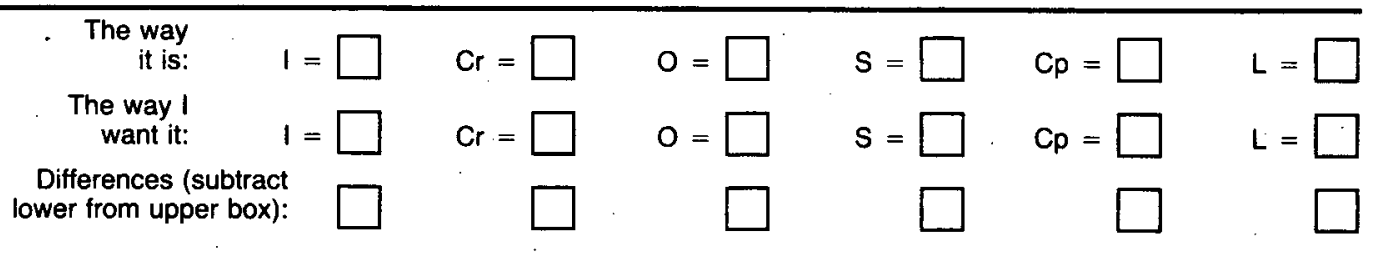




\section{The Schutz Measures}

\section{Interpretation Summary: Element R (You to Me)}

Write scores from the boxes at the bottom of the Response Sheet in the appropriate boxes below. Scores range from 0 to 9 . Zero (lowest score) means that you strongly disagree with the statement that names the scale; nine (highest score) means that you strongly agree with the statement.

\section{THE WAY IT IS}

I In my opinion, you include me. High: You include me in your social activities. You initiate contact and spend time with me. Low: You do not initiate contact with me and you spend very little time with me.

$\mathrm{Cr} \square$ In my opinion, you control me. High: When we are together you tend to take charge, give orders, exert influence, and make decisions.

Low: You do not control or influence me when we are together.

- $\square$ In my opinion, you are open with me. High: You have very few secrets from me, and you initiate being open with me.

Low: You are not open with me. You withhold information from me.

S In my opinion, you feel that I am significant.

High: You feel that I am a significant and important person and that I am of interest to you.

Low: You do not feel that 1 am an important person in your life, and you have no strong feelings, positive or negative, toward me.

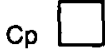

In my opinion, you feel that I am competent.

High: You feel that I am competent, that I have ability, and that I can make good decisions.

Low: You feel that I am not very competent and that I cannot be trusted to make good decisions.

$\mathrm{L} \square$ in my opinion you like me. High: You like me and you feel personal warmth toward me.

Low: You feel personally distant from me and perhaps you even dislike me.

\section{THE WAY I WANT}

$1 \square$ I want you to include me.

High: I want you to include me in your activities and to spend time with me.

Low: I do not want you to include me in your activities.

$\mathrm{Cr} \square$ I want you to control me.

High: I want you to control me and to tell me what to do.

Low: I do not want you to control or to influence me.

$0 \square$ I want you to be open with me. High: I want you to be open with me and not to withhold anything.

Low: I do not want you to be open with me. Keep your personal feelings to yourself.

$\mathrm{S}$ I want you to feel that I am significant.

High: I want you to feel that I am a significant person and that $\mathrm{I}$ am important to you.

Low: I do not want you to feel that I am important to you.

Cp $\square$ I want you to feel that I am competent.

High: I want you to feel that I am a competent, capable person.

Low: I do not want you to feel that I am competent.

\section{$L \square$ I want you to like me.}

High: I want you to like me and to feel personal warmth toward me.

Low: I do not want you to like me.
DIFFERENCE

Positive: You include me more than I want you to.

Negative: I want you to include me more than I feel that you do.

Positive: You control me more than I want you to.

Negative: I want you to control me more than I feel that you do.

Positive: You are open with me more than I want you to be.

Negative: I want you to be open with me more than I feel that you are.

Positive: You feel that I am more significant than want you to feel. Negative: I want you to feel that I am more significant than I think you do feel.

Positive: You feel that I am more competent than I want you to feel.

Negative: I want you to feel that I am more com petent than I think you do feel.

Positive: You like me more than I want you to. Negative: I want you to like me more than I think you do. 
The Schutz Measures Tabulation of Results

The Way It Is The Way I Want It Difference

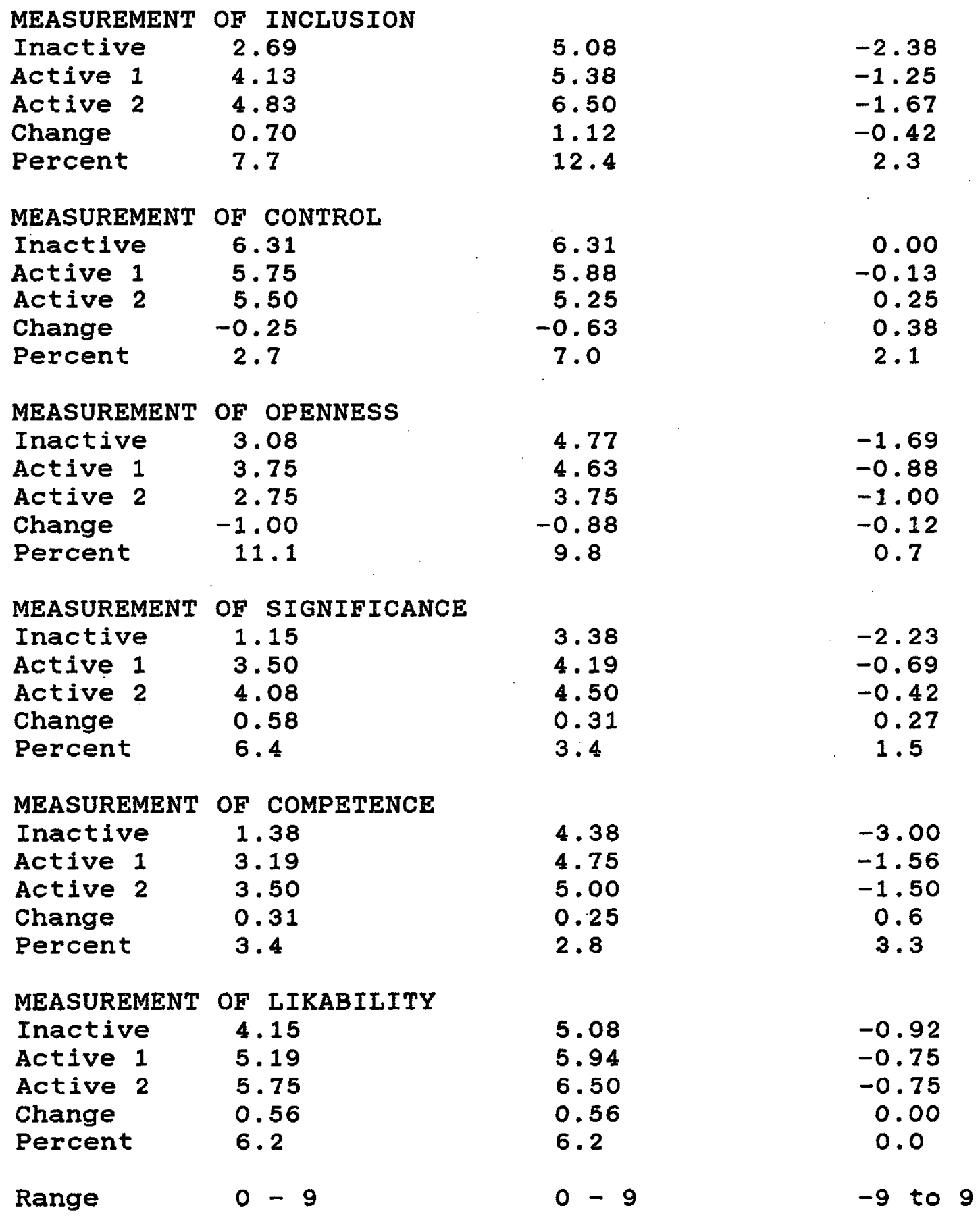




\section{BIBLIOGRAPHY}

\section{Books on Caring Ministries}

Bach, George R., and Torbet, Laura. A Time for Caring. New York: Delacorte Press, 1982.

Barr, Browne, and Eakin, Mary. The Ministering Congregation. Philadelphia: United Church Press, 1972 .

Bullmer, Kenneth. The Art of Empathy: A Manual for Improving Accuracy of Interpersonal Perception. New York: Behavioral Publications, 1975.

Caplovitz, David, and Sherrow, Fred. The Religious Drop-Outs: Apostasy Among College Graduates. Beverly Hills: Sage Publications, 1977.

Clemens, Bryan T., and Smith, Darrell. The Counselor and Religious Questioning and Conflicts. Boston: Houghton Mifflin Company, 1973 .

Clemmons, William, and Hester, Harvey. Growth Through Groups. Nashville: Broadman Press, 1974.

Detwiler-Zapp, Diane, and Dixon, William Caveness. Lay Caregiving. Philadelphia: Fortress Press, 1982.

Diehl, William E. Christianity and Real Iife. Philadelphia: Fortress Press, 1976.

- Thank God, It's Monday. Philadelphia: Fortress Press, 1982 .

Fast, Julius. Body Language. New York: M. Evans and Company, 1970.

Gerkin, Charles V. Crisis Experience in Modern Life. Nashville: Abingdon, 1979. 
Gibbs, Mark, and Morton, T. Ralph. Cod's Rrozen People. Philadelphia: Westminster Press, 1965.

Press, 1971 .

Gibbs, Mark. Christians with Secular Power. Philadelphia: Fortress Press, 1981 .

Kemp. Charles F. Prayer-Based Growth Groups. New York: Abingdon Press, 1974 .

Leslie, Robert C. Sharing Groups in the Church. Nashville: Abingdon Press, 1970.

Linberg, Edwin Carl. An Examination of the Role of the clergy as an Enabler of the Development and Growth of the Ministry of the Iaity. A project report, School of Theology, Claremont, California, 1975.

Oosterwal, Gottfried. Patterns of SDA Church Growth in America. Berrien Springs, MI: Andrews University Press, 1976 .

Richards, Lawrence 0 . A Theology of Personal Ministry. Spiritual Giftedness in the Local Church. Grand Rapids: Zondervan Publishing House, 1981.

Segler, Franklin M. A Theology of Church and Ministry. Nashvilie: Broadman Press, 1960

Snyder, Howard A. The Community of the King. Downers Grove, IL: Inter-Varsity Press, 1977 .

Southard, Samuel. Comprehensive Pastoral Care. Valley Forge, Pennsylvania: Judson Press, 1975.

------. Pastoral Evangelism. Atlanta, Georgia: John Knox Press, 1981 .

- - - - Tralning Church Members for Pastoral Care. Valley Forge, Pennsylvania: Judson Press, 1982.

Stone, Howard $W$. The Caring Church: A Guide for Lay Pastoral Care. San Francisco: Harper and Row, Publishers, 1983. 


\section{Books on Morship}

Bloy, Myron B. Jr., ed. Mult1-Media Worship: A Model and Nine Viewpoints. New York: Seabury Press, 1969.

Christensen, James $L$. Don't Naste Your Time in Worship. Old Tappan, NJ: Fleming $\mathrm{F}$. Revell Company, 1978.

Earnshaw, Leslie R. Worship for the Seventies. London: Cox \& Wyman, 1973 .

Feucht, Oscar E., ed. Christian Worship. Saint Louis: Concordia Publishing House, 1971.

Girard, Robert C. Brethren, Hang Loose. Grand Rapids: Zondervan Publishing House, 1972.

Holmes, C. Raymond. Sing a New Song. Berrien Springs, Michigan: Andrews University Press, 1984.

Nicholls, William. Jacob's Ladder: The Meaning of Worship. Richmond, Virginia: John Knox Press, 1958.

Ortlund, Anne. Op with Morship. Glendale, CA: G/L Publications, 1975.

Reaves, Benjamin Franklin. A study of Black Seventh-day Adventist Worship. Position paper presented to the Faculty of The Chicago Theological Seminary, 1974.

Robson, Edward A.. The Biblical Doctrine of Norship. Reformed Presbyterian Church of North America, 1974.

Rochelle, Jay C. Create and Celebrate. Philadelphia: Fortress Press, 1971.

Schuller, Robert H. Your Church Has Real Possibilities! Ventura California: Regal Books, 1974.

Segler, Franklin M. Christlan Norship, Its Theology and Practice. Nashville: Broadman Press, 1967.

Webber, Robert E. Worship Is a Verb. Waco, TX: Word Books, 1985 .

-- Morship: OId and New. Grand Rapids, MI : Zondervan, 1982. 
White, James F. Christian Worship in Transition. Nashville, TN: Abingdon, 1976. 1971.

Willimon, William H. Worship as Pastoral Care. Nashville, TN : Abingdon, 1979.

- The Service of God: Christian Work and Worship. Nashville, TN: Abingdon, 1983. 
VITA

1943 - 1958 CHILDHOOD

I grew up as a third generation Adventist in New England and California.

1958 - 1966 SCHOOLING

Academy and college were finished at Pacific Union College while my father was a physician at st. Helena Sanitarium.

1966 - 1968 SEMINARY

The Masters of Divinity degree was studied for and obtained at the Seminary at Andrews University.

1968 - 1975 PASTORATE Pastoring experiences were first in the Presque Isle, and then Woodstock, Maine districts of the Northern New England Conference.

1975 - 1981 PASTOR- For six years I taught Bible at TEACHER Rusangu Secondary School in Zambia Africa, and at times also pastored the school church which had an average attendance of 1,000 .

1981 - 1982 SEMINARY

After returning from Africa I studied towards the Doctor of Ministry degree at Andrews University.

1982 - 1985 PASTORATE Pastoring experiences were in. Garden City, Kansas and Omaha, Nebraska of the Kansas-Nebraska Conference.

1985 - 1987 SEMINARY Having returned to the seminary I finished the Doctor of Ministry degree graduating in June, 1987 . 